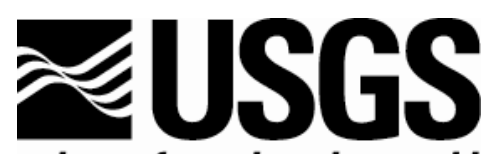

science for a changing world

Toxic Hydrology Program

\title{
Results of Chemical and Isotopic Analyses of Sediment and Water from Alluvium of the Canadian River near a Closed Municipal Landfill, Norman, Oklahoma
}

By George N. Breit, Michele L.W. Tuttle, Isabelle M. Cozzarelli, Scott C. Christenson, Jeanne B. Jaeschke, David L. Fey, and Cyrus J. Berry

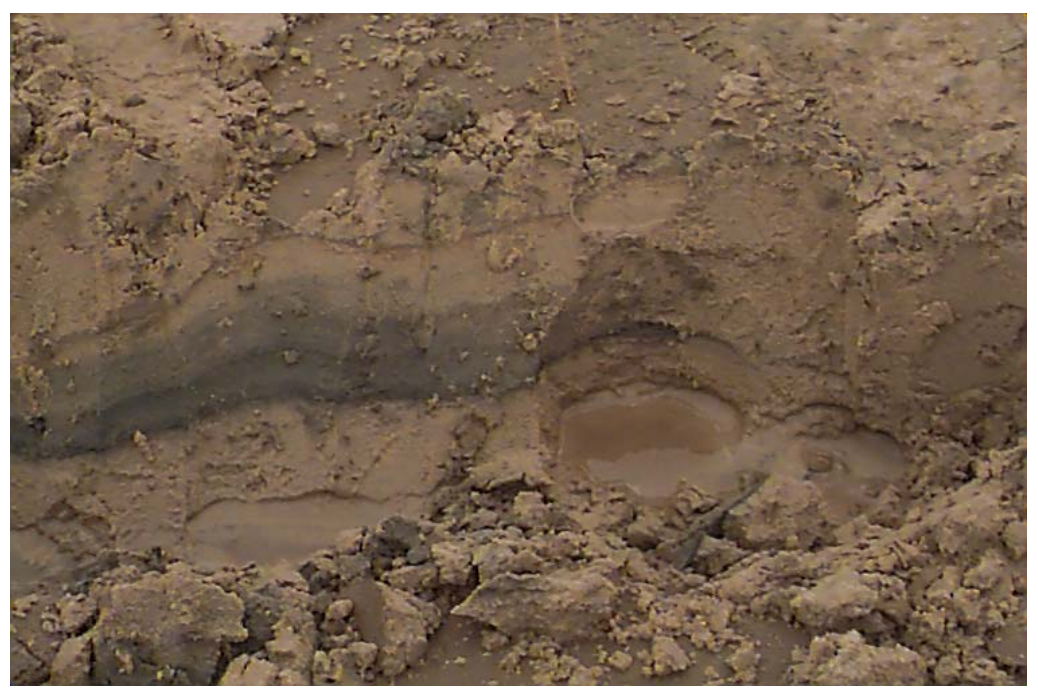

Open-File Report 2005-1091 


\title{
U.S. Department of the Interior \\ Gale A. Norton, Secretary
}

\section{U.S. Geological Survey \\ Charles G. Groat, Director}

\author{
U.S. Geological Survey, Reston, Virginia 2005 \\ Revised and reprinted: 2005
}

For product and ordering information:

World Wide Web: http://www.usgs.gov/pubprod

Telephone: 1-888-ASK-USGS

For more information on the USGS-the Federal source for science about the Earth, its natural and living resources, natural hazards, and the environment:

World Wide Web: http://www.usgs.gov

Telephone: 1-888-ASK-USGS

Cover Photograph of the wall of a shallow trench dug into north the bank of the Canadian River perpendicular to the river. Trench is approximately 1 foot deep and shows iron sulfide (black) phases coating the typically red sediment. Intensity of black coating increases toward the river.

Open-File Reports are used for the dissemination of information that must be released immediately to fill a public need or for information that is not sufficiently refined to warrant formal publication. As such, Open-File Reports should not be viewed as final reports of major scientific investigations. Because of their preliminary nature and possibility of being superseded, Open-file reports do not introduce new or revise geologic, stratigraphic, hydrologic or taxonomic nomenclature. In particular, Article 4(a) of the North American Stratigraphic Code excludes, Open-file releases for the naming or revising of formal geologic units. Use of brand names is intended for descriptive purposes only and does not represent an endorsement by the U.S. Geological Survey.

Although this report is in the public domain, permission must be secured from the individual copyright owners to reproduce any copyrighted material contained within this report. 


\section{Contents}

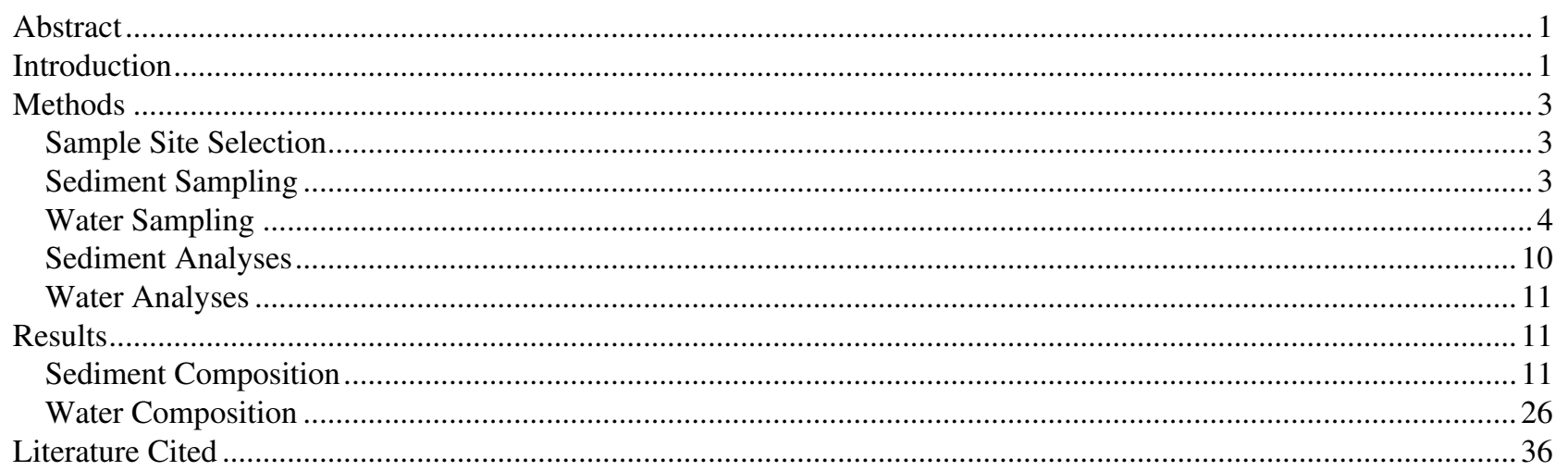




\section{Figures}

1. Map of freeze-shoe core and shallow sediment sample sites in the Canadian River alluvium.......................... 2

2. Lithologic characteristics of sediment recovered by freeze-shoe coring with locations of sediment and pore-water samples.

3. Map of locations of water samples collected from the Canadian River, New Mexico, Texas, and Oklahoma ...... 9

4. Ternary diagram of the relative abundance of sand, silt, and clay in sediment samples collected by freeze-shoe coring of the Canadian River alluvium.

5. Secondary electron micrograph images of pyrite from relatively shallow samples ( $<2$ meters) within the Canadian River alluvium.

6. Secondary electron and backscatter micrographs of massive pyrite aggregates from sediment samples of the Canadian River alluvium.

7. Secondary electron images of well-formed pyrite crystals from samples of the Canadian River alluvium below depths of 2 meters

8. Micrographs of barite detected within the Canadian River alluvium.

\section{Tables}

1. Locations and elevations of core sites and sampled wells

2. Description of sediment samples from the Canadian River alluvium. .................................................... 6

3. Time of collection and location of Canadian River water samples.................................................... 9

4. $\quad$ Results of particle-size analysis of sediment samples collected by freeze-shoe coring ............................ 12

5. Concentrations of iron extracted from sediment samples by treatment with $1 \mathrm{~N} \mathrm{KCl}, 0.5 \mathrm{M} \mathrm{HCl}$ and Ti3+-EDTA for 24 hours.

6. Content of organic carbon, forms of sulfur, and sulfur isotopic compositions of sediment samples. $\quad \ldots \ldots \ldots . . .27$

7. Chemical composition of pore water withdrawn directly from core of the Canadian River alluvium that was obtained by freeze-shoe coring.

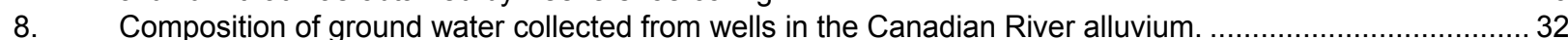

9. Chemical composition of water samples from the Canadian River ..................................................... 34 
CONVERSION FACTORS AND DATUMS

\begin{tabular}{|l|c|l|}
\hline \multicolumn{2}{|l|}{ Lultiply } & \multicolumn{2}{|l|}{ Length } & To obtain \\
\hline centimeter $(\mathrm{cm})$ & 0.3937 & inch (in.) \\
\hline meter $(\mathrm{m})$ & 3.281 & foot (ft) \\
\hline kilometer $(\mathrm{km})$ & 0.6214 & mile (mi) \\
\hline kilometer $(\mathrm{km})$ & 0.5400 & mile, nautical (nmi) \\
\hline liter $(\mathrm{L})$ & 33.82 & ounce, fluid (fl. oz) \\
\hline liter $(\mathrm{L})$ & 0.2642 & gallon (gal) \\
\hline liter $(\mathrm{L})$ & 61.02 & cubic inch (in $\left.{ }^{3}\right)$ \\
\hline cubic foot per second $\left(\mathrm{ft}^{3} / \mathrm{s}\right)$ & 0.0283 & cubic meter per second (m $\left.{ }^{3} / \mathrm{s}\right)$ \\
\hline gram $(\mathrm{g})$ & 0.03527 & ounce, avoirdupois $(\mathrm{oz})$ \\
\hline kilogram $(\mathrm{kg})$ & 2.205 & pound avoirdupois $(\mathrm{lb})$ \\
\hline
\end{tabular}

Temperature in degrees Celsius $\left({ }^{\circ} \mathrm{C}\right)$ may be converted to degrees Fahrenheit $\left({ }^{\circ} \mathrm{F}\right)$ as follows:

$$
{ }^{\circ} \mathrm{F}=\left(1.8 \times{ }^{\circ} \mathrm{C}\right)+32
$$

Vertical coordinate information is referenced to the insert datum name (and abbreviation) here, for instance, "North American Vertical Datum of 1988 (NAVD 88)" Horizontal coordinate information is referenced to the insert datum name (and abbreviation) here, for instance, "North American Datum of 1983 (NAD 83)"

Altitude, as used in this report, refers to distance above the vertical datum.

Specific conductance is given in microsiemens per centimeter at 25 degrees Celsius $\left(\mu \mathrm{S} / \mathrm{cm}\right.$ at $\left.25^{\circ} \mathrm{C}\right)$. Concentrations of chemical constituents in water are given either in milligrams per liter $(\mathrm{mg} / \mathrm{L})$ or micrograms per liter $(\mu \mathrm{g} / \mathrm{L})$.

\section{Abbreviated Units}

Chemical concentration and water temperature are given only in metric units. Chemical concentration in water is given as milligrams per liter $(\mathrm{mg} / \mathrm{L})$ or micrograms per liter $(\mu \mathrm{g} / \mathrm{L})$. Chemical concentrations in solid phase samples are given as weight percent (wt.\%), parts per million (ppm), millimoles per gram (mmol/g), or micromoles per gram $(\mu \mathrm{mol} / \mathrm{g})$. Grain size abundances are listed in volume percent (volume \%). Stableisotope ratios are reported relative to internationally agreed upon standards. Deviations from standards are expressed in per mil (\%o) using the delta $(\delta)$ notation. The delta symbol in this report is followed by the chemical symbol for the heavier isotope measured during isotopic analysis. 


\section{Abbreviated Chemical Symbols}

\begin{tabular}{|c|c|}
\hline $\mathrm{Ag}$ & Silver \\
\hline $\mathrm{Al}$ & Aluminum \\
\hline As & Arsenic \\
\hline B & Boron \\
\hline $\mathrm{Ba}$ & Barium \\
\hline $\mathrm{Be}$ & Beryllium \\
\hline $\mathrm{Ca}$ & Calcium \\
\hline $\mathrm{Cd}$ & Cadmium \\
\hline Co & Cobalt \\
\hline $\mathrm{Cr}$ & Chromium \\
\hline Cs & Cesium \\
\hline $\mathrm{Cu}$ & Copper \\
\hline $\mathrm{Fe}$ & Iron \\
\hline $\mathrm{Fe}^{2+}$ & Ferrous iron \\
\hline $\mathrm{Fe}^{3+}$ & Ferric iron \\
\hline K & Potassium \\
\hline $\mathrm{Li}$ & Lithium \\
\hline $\mathrm{Mg}$ & Magnesium \\
\hline $\mathrm{Mn}$ & Manganese \\
\hline Мо & Molybdenum \\
\hline $\mathrm{Ni}$ & Nickel \\
\hline $\mathrm{O}_{\mathrm{sO} 4}$ & Sulfate oxygen \\
\hline $\mathrm{Pb}$ & Lead \\
\hline $\mathrm{Rb}$ & Rubidium \\
\hline S & Sulfur \\
\hline $\mathrm{S}_{\mathrm{AV}}$ & Acid-volatile sulfur \\
\hline $\mathrm{S}_{\mathrm{DI}}$ & Disulfide sulfur \\
\hline $\mathrm{S}_{\mathrm{SO} 4}$ & Sulfate sulfur \\
\hline $\mathrm{Sb}$ & Antimony \\
\hline $\mathrm{Se}$ & Selenium \\
\hline $\mathrm{Si}$ & Silicon \\
\hline $\mathrm{Sr}$ & Strontium \\
\hline $\mathrm{Ti}$ & Titanium \\
\hline $\mathrm{U}$ & Uranium \\
\hline V & Vanadium \\
\hline $\mathrm{Zn}$ & Zinc \\
\hline
\end{tabular}




\section{Results of Chemical and Isotopic Analyses of Sediment and Water from Alluvium of the Canadian River near a Closed Municipal Landfill, Norman, Oklahoma}

By George N. Breit, Michele L.W. Tuttle, Isabelle M. Cozzarelli, Scott C. Christenson, Jeanne B. Jaeschke, David L. Fey, and Cyrus J. Berry

\section{Abstract}

Results of physical and chemical analyses of sediment and water collected near a closed municipal landfill at Norman, Oklahoma are presented in this report. Sediment analyses are from 40 samples obtained by freeze-shoe coring at 5 sites, and 14 shallow (depth $<1.3 \mathrm{~m}$ ) sediment samples. The sediment was analyzed to determine grain size, the abundance of extractable iron species and the abundances and isotopic compositions of forms of sulfur. Water samples included pore water from the freeze-shoe core, ground water, and surface water. Pore water from 23 intervals of the core was collected and analyzed for major and trace dissolved species. Thirteen ground-water samples obtained from wells within a few meters of the freeze-shoe core sites and one from the landfill were analyzed for major and trace elements as well as the sulfur and oxygen isotope composition of dissolved sulfate. Samples of surface water were collected at 10 sites along the Canadian River from New Mexico to central Oklahoma. These river-water samples were analyzed for major elements, trace elements, and the isotopic composition of dissolved sulfate.

\section{Introduction}

Thousands of municipal landfills were sited adjacent to rivers prior to the passage of regulations intended to restrict the impact of solid wastes and leachates produced by interaction of ground water and surface water with those wastes. The U.S. Geological Survey (USGS) Toxic Hydrology Program is supporting the study of a closed municipal landfill located on Canadian River alluvium near the city of Norman, Oklahoma, to evaluate the environmental impact of one of these waste repositories. The closed Norman municipal landfill operated in varying forms from 1922 until 1985 on the north bank of the Canadian River. Initially the wastes were dispersed along the banks of the river. Beginning in 1960, the operators excavated trenches to the water table and buried wastes beneath $15 \mathrm{~cm}$ of sand (Schlottmann, 2001). Trenches were abandoned in 1971, and wastes were deposited on lifts of sand 0.6 meter above the water table. Wastes were buried daily with sand. The landfill was closed in 1985 and covered with a low permeability cap leaving two mounds rising about 12 meters above the surrounding land surface (Schlottmann, 2001) (fig. 1). 


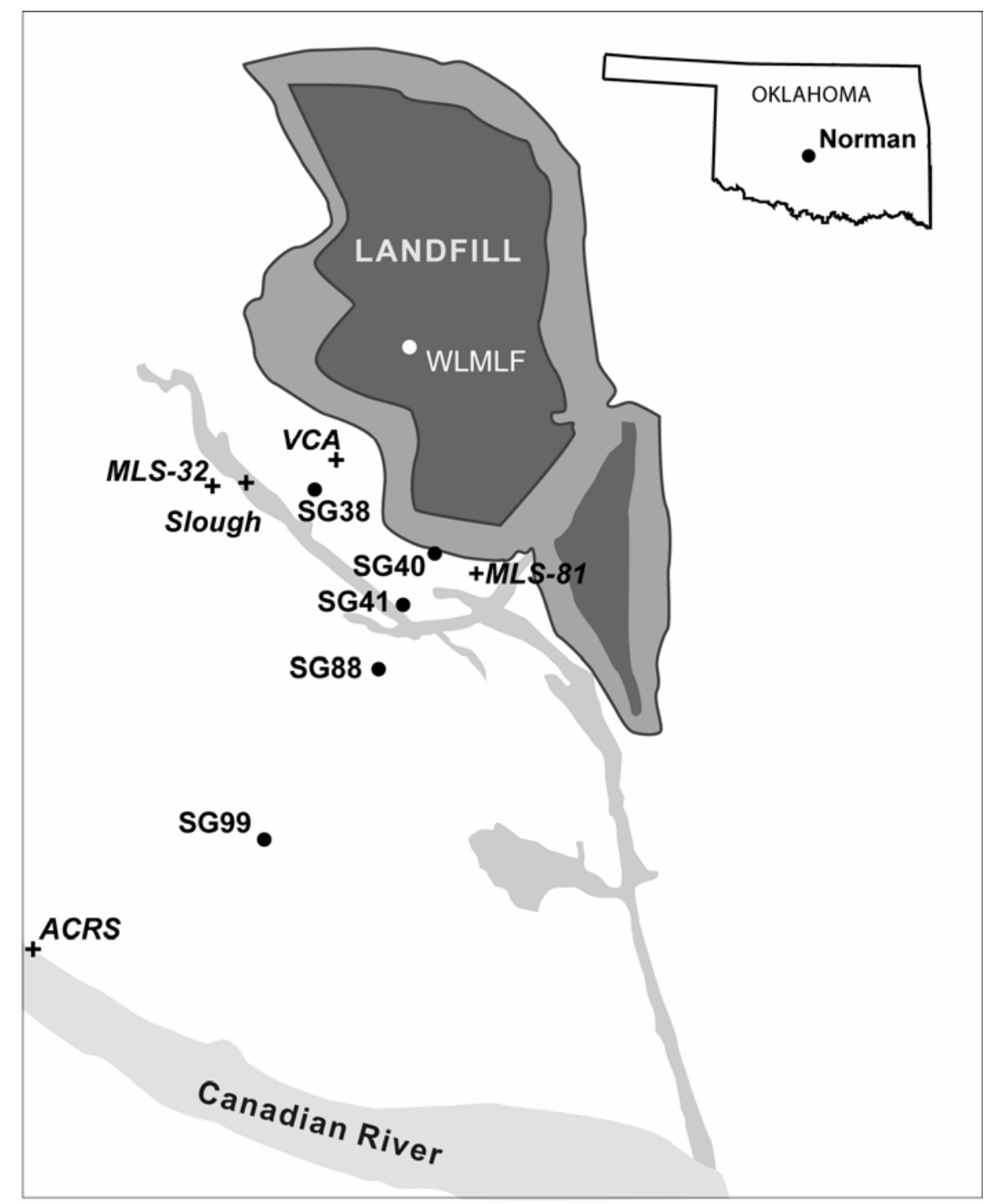

\section{$200 \mathrm{~m}$}

Figure 1. Map of freeze-shoe core $(\bullet)$ and shallow sediment sample sites $(+)$ near the closed Norman municipal landfill. Details of locations and depths are presented in table 1.

Movement of water through the waste produces a leachate recognizable by high specific conductance, dissolved organic carbon, iron, methane, ammonium, and boron (Schlottmann, 2001). Processes that attenuate the organic contaminants as the leachate moves through the Canadian River alluvium are a primary emphasis of the USGS project. A set of processes collectively identified as natural attenuation results in the degradation of organic matter through bacterial oxidation of organic components of the leachate. Bacterial oxidation of the organic compounds requires the presence of electron acceptors such as dissolved oxygen, nitrate, manganese oxides, ferric iron, or sulfate. This report presents data on the abundance of iron and sulfur species in the sediment that will be used to gauge the significance of ferric iron and sulfate as electron acceptors. Sediment and pore water collected by coring, ground water collected from established wells, shallow alluvial sediment and surface-water samples were analyzed. Results show the impact of leachate on the speciation of iron and sulfur in the alluvium downgradient of the landfill can be detected. Nonetheless, the effects of the leachate are small relative to the effects of natural processes evident in the composition of sediment unaffected by leachate. 


\section{Methods}

\section{Sample Site Selection}

The extent of the landfill leachate was described by surface geophysics (Lucius and Bisdorf, 1995) and through profiling the electrical conductivity of the ground water (Becker, 2002; Christenson, 1999, USGS written commun.). Coupled with existing knowledge of the hydrologic and lithologic characteristics of the Canadian River alluvium (Scholl and Christenson, 1998), sites SG40, SG38, SG41, SG88, and SG99 (table 1, fig. 1) were selected to represent sediment with varied exposure to landfill leachate. The depth profiles of the specific conductance of water at SG40, SG38, SG41, and SG88 using measurements collected in 1995 and 1997 are presented in Becker (2002). SG40 and SG38 are intended to represent sediment with sustained exposure to leachate. The specific conductance of ground water in the cored interval from site SG41 increased sharply from 1997 to $1999\left(1000\right.$ to $4000 \mu \mathrm{S} \mathrm{cm}^{-1}$ at some depths; Christenson, 1999, written commun.) and is interpreted to represent advance of the leachate down the hydrologic gradient from the landfill toward the Canadian River. Ground water extracted near site SG88 is consistent with background water compositions, although sediment samples collected at SG88 had a distinctive odor consistent with the presence of leachate. This may indicate some exposure of SG88 sediment to leachate. SG99 is approximately 400 meters $(\mathrm{m})$ south of the west landfill cell in an area beyond the extent of the recognized leachate plume within the sampled depth range.

Table 1. Locations and elevations of core sites and sampled wells.

\begin{tabular}{|c|c|c|c|c|}
\hline Core or Well & $\begin{array}{l}\text { Land surface } \\
\text { elevation } \\
\text { (meters) }\end{array}$ & Latitude & Longitude & $\begin{array}{l}\text { Elevation of cored (C) } \\
\text { or well screen (WS) } \\
\text { Intervals (meters) }\end{array}$ \\
\hline SG38 & 331.4 & N $35.1669869^{\circ}$ & W $97.4468026^{\circ}$ & C 328.3 to 326.2 \\
\hline MLS38-3 & 331.38 & N $35.1669150^{\circ}$ & W $97.4468234^{\circ}$ & WS $328.14 \quad 328.02$ \\
\hline MLS38-5 & 331.38 & N $35.1669150^{\circ}$ & W $97.4468234^{\circ}$ & WS 325.24 to 325.13 \\
\hline SG40 & 330.7 & N $35.1664534^{\circ}$ & W $97.4455642^{\circ}$ & C 328.0 to 325.9 \\
\hline MLS40-2 & 330.61 & N $35.1664307^{\circ}$ & W $97.4455423^{\circ}$ & WS 328.02 to 327.90 \\
\hline MLS40-3 & 330.61 & N $35.1664307^{\circ}$ & W $97.4455423^{\circ}$ & WS 327.02 to 326.90 \\
\hline MLS40-4 & 330.61 & N $35.1664307^{\circ}$ & W $97.4455423^{\circ}$ & WS 326.03 to 325.91 \\
\hline SG41 & 330.3 & N $35.1660014^{\circ}$ & W $97.4458382^{\circ}$ & C 326.6 to 324.5 \\
\hline MLS41-3 & 330.35 & N $35.1659850^{\circ}$ & W $97.4458571^{\circ}$ & WS 327.84 to 327.72 \\
\hline MLS41-4 & 330.35 & N $35.1659850^{\circ}$ & W $97.4458571^{\circ}$ & WS 326.84 to 326.72 \\
\hline SG88-2 & 330.3 & N $35.1654111^{\circ}$ & W $97.4461434^{\circ}$ & C 327.4 to 325.3 \\
\hline SG88-3 & 330.3 & N $35.1654191^{\circ}$ & W 97.4461610 & C 328.2 to 326.1 \\
\hline MLS88-3 & 330.40 & N $35.1653763^{\circ}$ & W $97.4461498^{\circ}$ & WS 327.61 to 327.49 \\
\hline MLS88-4 & 330.40 & N $35.1653763^{\circ}$ & W $97.4461498^{\circ}$ & WS 326.67 to 326.56 \\
\hline SG99 & 330.4 & N $35.1636689^{\circ}$ & W $97.4475289^{\circ}$ & C 327.1 to 324.9 \\
\hline SG99-S1 & 330.3 & N $35.1636559^{\circ}$ & W $97.4475289^{\circ}$ & WS 326.5 to 326.2 \\
\hline SG99-S2 & 330.3 & N $35.1636559^{\circ}$ & W $97.4475289^{\circ}$ & WS 325.5 to 325.2 \\
\hline SG99-S3 & 330.3 & N $35.1636559^{\circ}$ & W $97.4475289^{\circ}$ & WS 324.5 to 324.2 \\
\hline WLMLF & 343.10 & N $35.1684982^{\circ}$ & W $97.4457245^{\circ}$ & WS 330.47 to 328.95 \\
\hline MLS32 & 330.5 & N $35.1671867^{\circ}$ & W $97.4480325^{\circ}$ & C 329.16 to 329.04 \\
\hline MLS81 & 330.7 & N $35.1663427^{\circ}$ & W $97.4450597^{\circ}$ & C 329.42 to 329.30 \\
\hline
\end{tabular}




\section{Sediment Sampling}

Canadian River alluvium was sampled in May of 2000. At each site, sediment was collected within the depth interval of 2 to $6 \mathrm{~m}$. This depth range was selected to sample above the high permeability of coarse sands and gravels characteristic of the lower third of the alluvium (Scholl and Christenson, 1998) and to minimize the influence of the fluctuating water table to only the uppermost portions of the core (Becker, 2002). Subsurface sampling used a freeze-shoe coring device with a hollow-stem auger. The freeze-shoe coring device captures sediment and enclosed pore water by freezing the lowest sediment in the core barrel by circulating liquid carbon dioxide through the bit (Murphy and Herkelrath, 1996). During the sampling, sediment and enclosed pore water were captured in transparent acrylic core liners. The liners were cut into approximately 2 -foot lengths subsequent to the water sampling described below, sealed with end caps that were taped shut, and transported in "ammo cans" purged with nitrogen. The cans containing the core were refrigerated in the microbiology laboratories of Dr. Joseph Suflita at the University of Oklahoma, 4 miles from the study site. Shallow sediment samples were collected from the active Canadian River (ACRS), the slough, and near the water table by using a hand trowel, shovel, and a hollow-stem auger. The shallow sediments were stored in glass vials, plastic containers, and acrylic core liners that were frozen on site with dry ice.

Core liners from the freeze-shoe coring were cut and split using a knife in a glove box filled with nitrogen and a small amount of hydrogen. The oxygen-free integrity of the atmosphere within the glove box was ensured using a palladium catalyst. Each length of core was described and divided by apparent grain size and color variations into separate samples (table 2, fig. 2). Each visually distinct interval was homogenized in a plastic beaker and subsampled. A 3-milliliter $(\mathrm{mL})$ detipped syringe was used to transfer an aliquot of sediment into acid-washed serum vials for iron speciation analysis. Each vial was wrapped in foil to minimize exposure to light during treatment with iron speciation reagents. A 10-mL detipped syringe was used to transfer an aliquot of the sediment into amber septa vials. These vials were frozen immediately after removal from the glove box for later speciation of the sulfur forms. A separate aliquot was frozen for later freeze drying and examination with the scanning electron microscope (SEM).

\section{Water Sampling}

Water was collected from the cored sediment, existing wells, drive point wells and surface water. Water extracted from the cored sediment was withdrawn with a syringe through small holes drilled in the liner. The voids produced by the withdrawn water were filled with nitrogen provided through a pressurized cap placed on top of the liner. Where sufficient water was recovered, $\mathrm{pH}$, alkalinity, ferrous iron, and ammonium were determined in the field. A small aliquot of water was filtered $(<0.1 \mu \mathrm{m})$ and acidified with nitric acid to a $\mathrm{pH}<2$ for analysis of cations and trace elements. A second filtered aliquot was preserved on ice for analysis of anions. Filtered water stored in a baked glass bottle was used for dissolved organic carbon. Unfiltered water also was placed in a tightly sealed glass bottle and refrigerated for determination of methane concentration.

Ground water was recovered with a peristaltic pump from existing wells (MLS38, MLS40, MLS41, MLS88, and WLMLF) and from stainless steel drive point wells (SG99-1, SG99-2, and SG99-3). After conductivity and $\mathrm{pH}$ became constant, the samples were filtered through an inline $0.45 \mu \mathrm{m}$ filter and stored on ice for transport.

In April of 2002, Water samples along the length of the Canadian River from New Mexico to central Oklahoma (fig. 3, table 3) were collected from the river bank in reaches with visible flow. Stagnant pools on the margin of the main channel near the landfill also were sampled. Measurements of electrical conductivity, temperature, and $\mathrm{pH}$ were made directly on the water source using calibrated meters. A beaker or syringe was used to collect the water. Water was filtered to $<0.2$ um for cation and anion analysis with a syringe filter. Cation samples were acidified with nitric acid to a $\mathrm{pH}<2$. Raw water samples were collected to recover sulfate for isotopic analyses and alkalinity determinations. The raw water and anion samples were transported in an ice-filled cooler. 


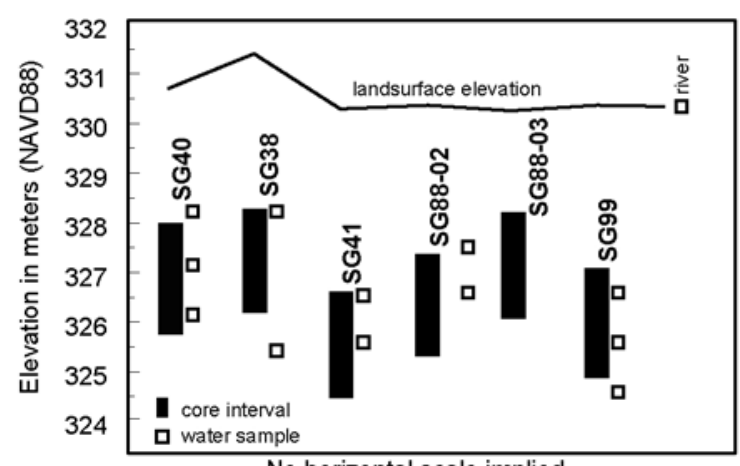

No horizontal scale implied
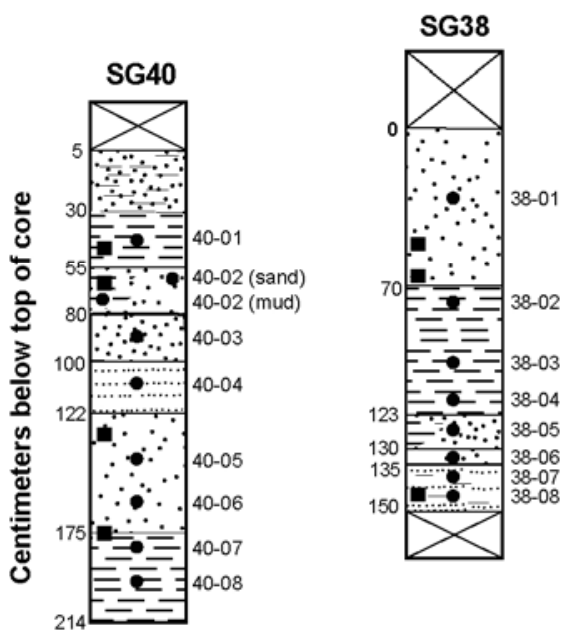

\section{EXPLANATION}

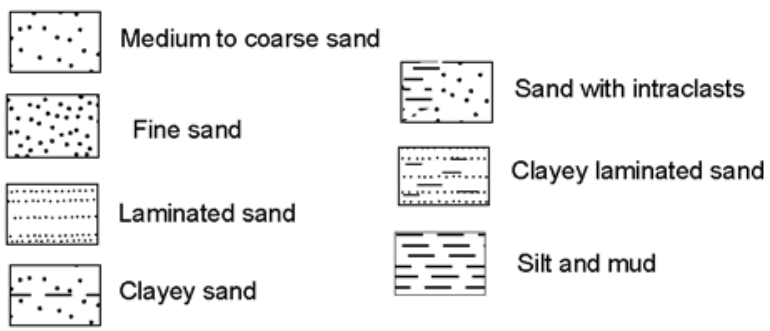

- Sediment sample

- Porewater sample
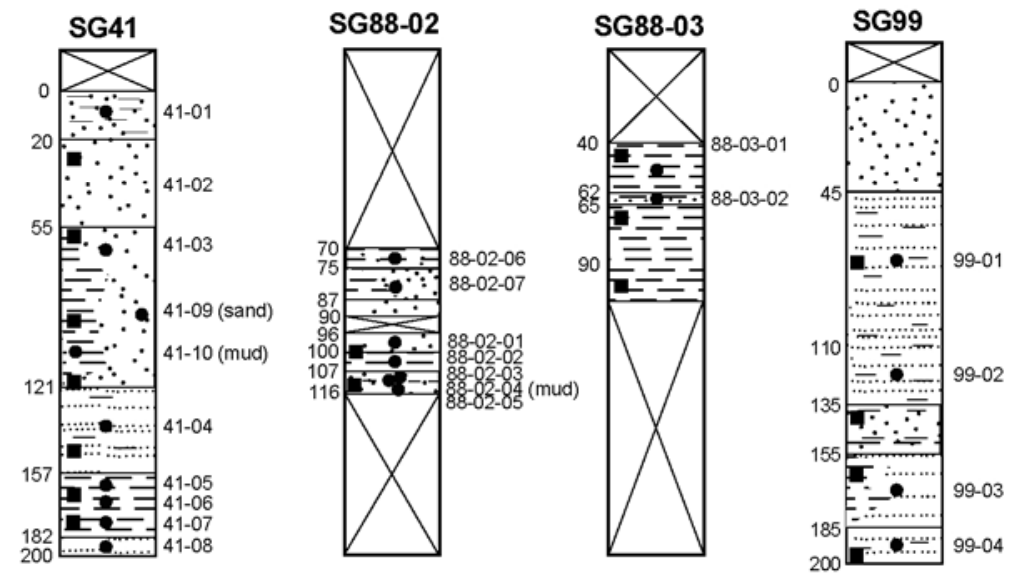

Figure 2. Lithologic characteristics of sediment cored by freeze-shoe coring with locations of sediment and porewater samples. Locations of screened wells within a few meters of the core sites that were sampled to collect ground water are indicated in the inset. Detailed descriptions and locations of samples are listed in tables 1 and 2. 
Table 2. Description of sediment samples from the Canadian River alluvium.

[Colors were assigned to air-dried samples using color chart of Goddard and others (1979). Separate colors were assigned to sand (S) and mud fractions (M) of most samples. ACRS (active Canadian River sediment) identifies samples of shallow sediment collected near and within the active channel of the river. --- , not determined]

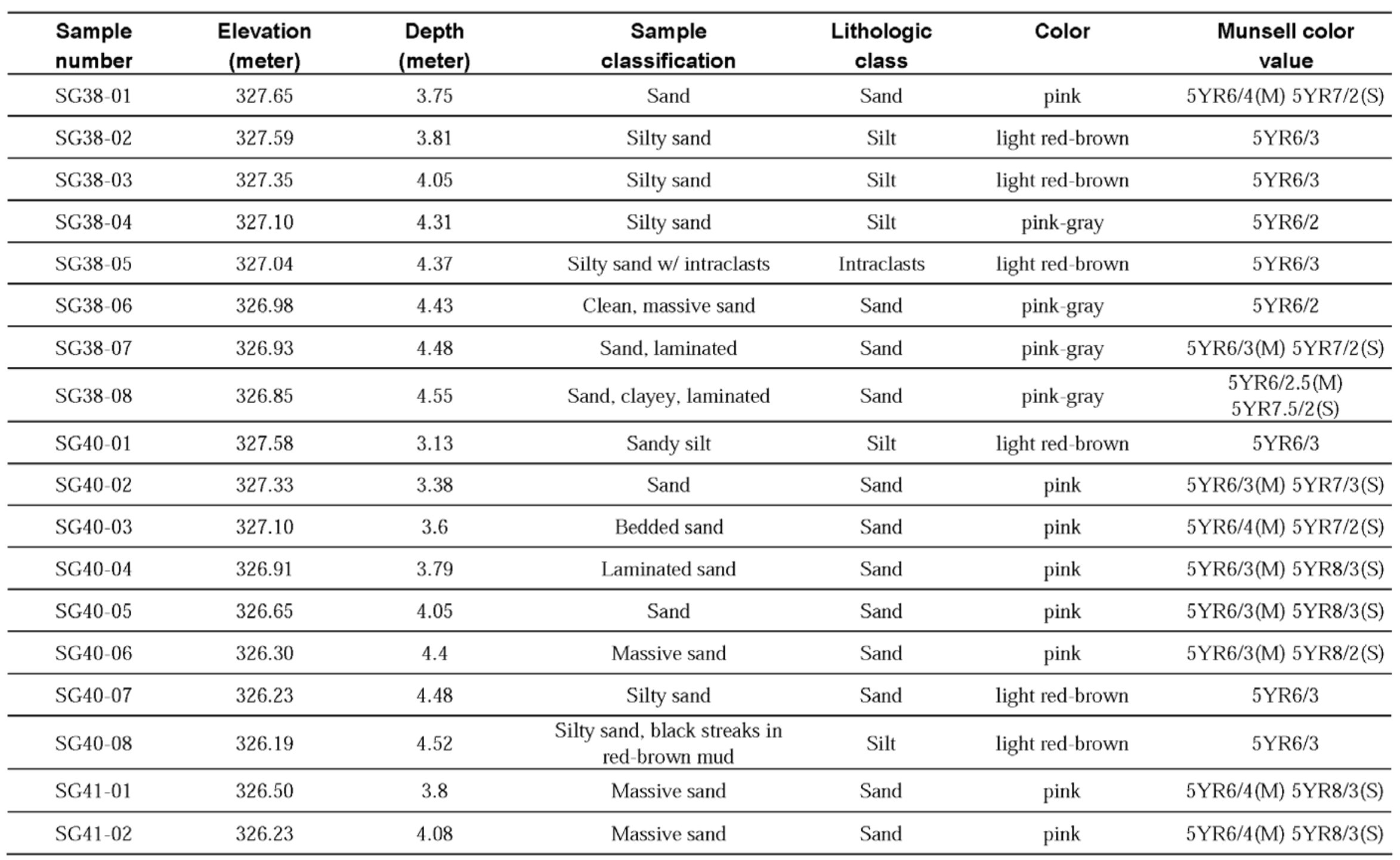


Table 2. Description of sediment samples from the Canadian River alluvium — Continued

\begin{tabular}{|c|c|c|c|c|c|c|}
\hline $\begin{array}{l}\text { Sample } \\
\text { number }\end{array}$ & $\begin{array}{l}\text { Elevation } \\
\text { (meter) }\end{array}$ & $\begin{array}{l}\text { Depth } \\
\text { (meter) }\end{array}$ & $\begin{array}{c}\text { Sample } \\
\text { classification }\end{array}$ & $\begin{array}{l}\text { Lithologic } \\
\text { class }\end{array}$ & Color & $\begin{array}{c}\text { Munsell color } \\
\text { value }\end{array}$ \\
\hline SG41-03 & 325.94 & 4.36 & Massive sand & Sand & pink & $\begin{array}{c}\text { 5YR6/4(M) } \\
5 \mathrm{YR} 8 / 3(\mathrm{~S}) \\
\end{array}$ \\
\hline SG41-04 & 325.18 & 5.12 & Sand, finely laminated, medium & Sand & light red-brown & $\begin{array}{c}5 \mathrm{YR} 7 / 3(\mathrm{~S}) \\
5 \mathrm{YR} 5 / 3(\mathrm{M})\end{array}$ \\
\hline SG41-05 & 324.97 & 5.34 & $\begin{array}{l}\text { Intraclast conglomerate with sand } \\
\text { matrix }\end{array}$ & Intraclasts & light red-brown & $5 \mathrm{YR} 6 / 2.5(\mathrm{M})$ \\
\hline SG41-06 & 324.85 & 5.45 & $\begin{array}{l}\text { Intraclast conglomerate with sand } \\
\text { matrix }\end{array}$ & Intraclasts & light red-brown & 5YR6/3 \\
\hline SG41-07 & 324.86 & 5.44 & $\begin{array}{l}\text { Intraclast conglomerate with sand } \\
\text { matrix }\end{array}$ & Intraclasts & light red-brown & 5YR6.5/4 \\
\hline SG41-08 & 324.57 & 5.73 & Sand, laminated & Sand & pink & $\begin{array}{l}5 \mathrm{YR} 7 / 4(\mathrm{M}) \\
5 \mathrm{YR} 8 / 2(\mathrm{~S})\end{array}$ \\
\hline SG41-09 & 325.58 & 4.73 & Sand, medium & Sand & light red-brown & $\begin{array}{l}5 \mathrm{YR} 6 / 4(\mathrm{M}) \\
5 \mathrm{YR} 7 / 3(\mathrm{~S})\end{array}$ \\
\hline SG41-10 & 325.58 & 4.73 & $\begin{array}{l}\text { Intraclast conglomerate with sand } \\
\text { matrix }\end{array}$ & Intraclasts & light red-brown & 5YR6/4 \\
\hline SG88-02-01 & 326.42 & 3.88 & Sand, coarse & Sand & gray & N7 \\
\hline SG88-02-02 & 326.37 & 3.94 & $\begin{array}{l}\text { Intraclast conglomerate with sand } \\
\text { matrix }\end{array}$ & Intraclasts & gray & N7 \\
\hline SG88-02-03 & 326.31 & 4 & Silty sand, coarse & Sand & gray & N7 \\
\hline SG88-02-04 & 326.28 & 4.03 & $\begin{array}{l}\text { Intraclast conglomerate with sand } \\
\text { matrix }\end{array}$ & Intraclasts & light red-brown & 5 YR6/3 \\
\hline SG88-02-05 & 326.26 & 4.05 & $\begin{array}{c}\text { Sand, coarse with few granule } \\
\text { intraclasts }\end{array}$ & Sand & gray & $\begin{array}{l}\text { 5YR6.5/3(M) } \\
\text { N5(S) } \\
\end{array}$ \\
\hline SG88-02-06 & 326.69 & 3.62 & Silt, sandy & Silt & pink & --- \\
\hline SG88-02-07 & 326.60 & 3.71 & $\begin{array}{c}\text { Intraclast conglomerate with } \\
\text { sandy matrix and plant fragments }\end{array}$ & Intraclasts & light red-brown & $5 Y R 6 / 3$ \\
\hline SG88-03-01 & 327.61 & 2.7 & $\begin{array}{l}\text { Silt, sandy with pyrite on bedding } \\
\text { planes }\end{array}$ & Silt & light red-brown & 5YR6/4 \\
\hline
\end{tabular}


Table 2. Description of sediment samples from the Canadian River alluvium — Continued

\begin{tabular}{|c|c|c|c|c|c|c|}
\hline $\begin{array}{l}\text { Sample } \\
\text { number }\end{array}$ & $\begin{array}{c}\text { Elevation } \\
\text { (meter) }\end{array}$ & $\begin{array}{l}\text { Depth } \\
\text { (meter) }\end{array}$ & $\begin{array}{c}\text { Sample } \\
\text { classification }\end{array}$ & $\begin{array}{l}\text { Lithologic } \\
\text { class }\end{array}$ & Color & $\begin{array}{c}\text { Munsell color } \\
\text { value }\end{array}$ \\
\hline SG88-03-02 & 327.56 & 2.74 & Sand, silty & Silt & brown & Not determined \\
\hline SG88-03-03 & 326.34 & 3.97 & Sand, massive & Sand & pink & $5 \mathrm{YR} 8 / 2$ \\
\hline SG99-01 & 326.44 & 3.96 & Sand, weakly bedded & Sand & pink & $\begin{array}{l}5 \mathrm{YR} 6 / 4(\mathrm{M}) \\
5 \mathrm{YR} 8 / 2(\mathrm{~S})\end{array}$ \\
\hline SG99-02 & 325.88 & 4.53 & Sand, laminated & Sand & pink & $\begin{array}{l}5 \mathrm{YR} 6 / 3(\mathrm{M}) \\
5 \mathrm{YR} 7 / 3(\mathrm{~S}) \\
\end{array}$ \\
\hline SG99-03 & 325.43 & 4.98 & $\begin{array}{l}\text { Intraclast conglomerate with } \\
\text { sand matrix, }\end{array}$ & Intraclasts & $\begin{array}{c}\text { light } \\
\text { red-brown }\end{array}$ & $5 \mathrm{YR} 6 / 3$ \\
\hline SG99-04 & 325.17 & 5.24 & Sand, finely laminated & Sand & pink-gray & $5 Y R 7 / 2$ \\
\hline Slough Sed.-99a & 329.70 & 0.5 & Sand, fine & Sand & gray & N4 \\
\hline Slough Sed.-99b & 329.70 & 0.5 & Sand, fine & Sand & gray & N4 \\
\hline Slough Sed.-99b & 329.20 & 0 & Sand, fine & Sand & gray & N4 \\
\hline ACRS-99 & $\sim 328$ & 0.2 & Sand, bedded medium & Sand & gray & N7 \\
\hline ACRS-00a & $\sim 328$ & 0 & Sand, bedded medium & Sand & gray & N7 \\
\hline ACRS-00b & $\sim 328$ & 0 & Silt, sand and mud bedded & Silt & gray & N7 \\
\hline ACRS-02a & $\sim 328$ & 0.1 & $\begin{array}{l}\text { Sand, bedded, on active bar } \\
\text { in channel }\end{array}$ & Sand & red-brown -black & --- \\
\hline $\begin{array}{c}\text { ACRS-02b } \\
\text { (proximal pond) }\end{array}$ & $\sim 328$ & 0.2 & $\begin{array}{c}\text { Sand, silty } 2 \mathrm{~m} \text { from active } \\
\text { channel }\end{array}$ & Silt & red-brown-/ black & --- \\
\hline $\begin{array}{l}\text { ACRS-02c } \\
\text { (distal pond) }\end{array}$ & $\sim 328$ & 0.2 & $\begin{array}{l}\text { Sand, silty } 10 \mathrm{~m} \text { from the } \\
\text { active channel }\end{array}$ & Silt & red-brown / black & --- \\
\hline ACRS-02d & $\sim 328$ & 0.1 & $\begin{array}{c}\text { Sand bedded, surface of } \\
\text { active bar in channel }\end{array}$ & Sand & pink & $5 \mathrm{YR} 8 / 3$ \\
\hline ACRS-02e & $\sim 328$ & 0.3 & $\begin{array}{l}\text { Sand, bedded, from eroding } \\
\text { river bank }\end{array}$ & Sand & pink & $5 Y R 8 / 3$ \\
\hline MLS32 & 329.1 & 1.4 & Sand, silty & Silt & red-brown / black & -- \\
\hline MLS81 & 329.4 & 1.3 & Sand, silty & Silt & red-brown / black & -- \\
\hline
\end{tabular}




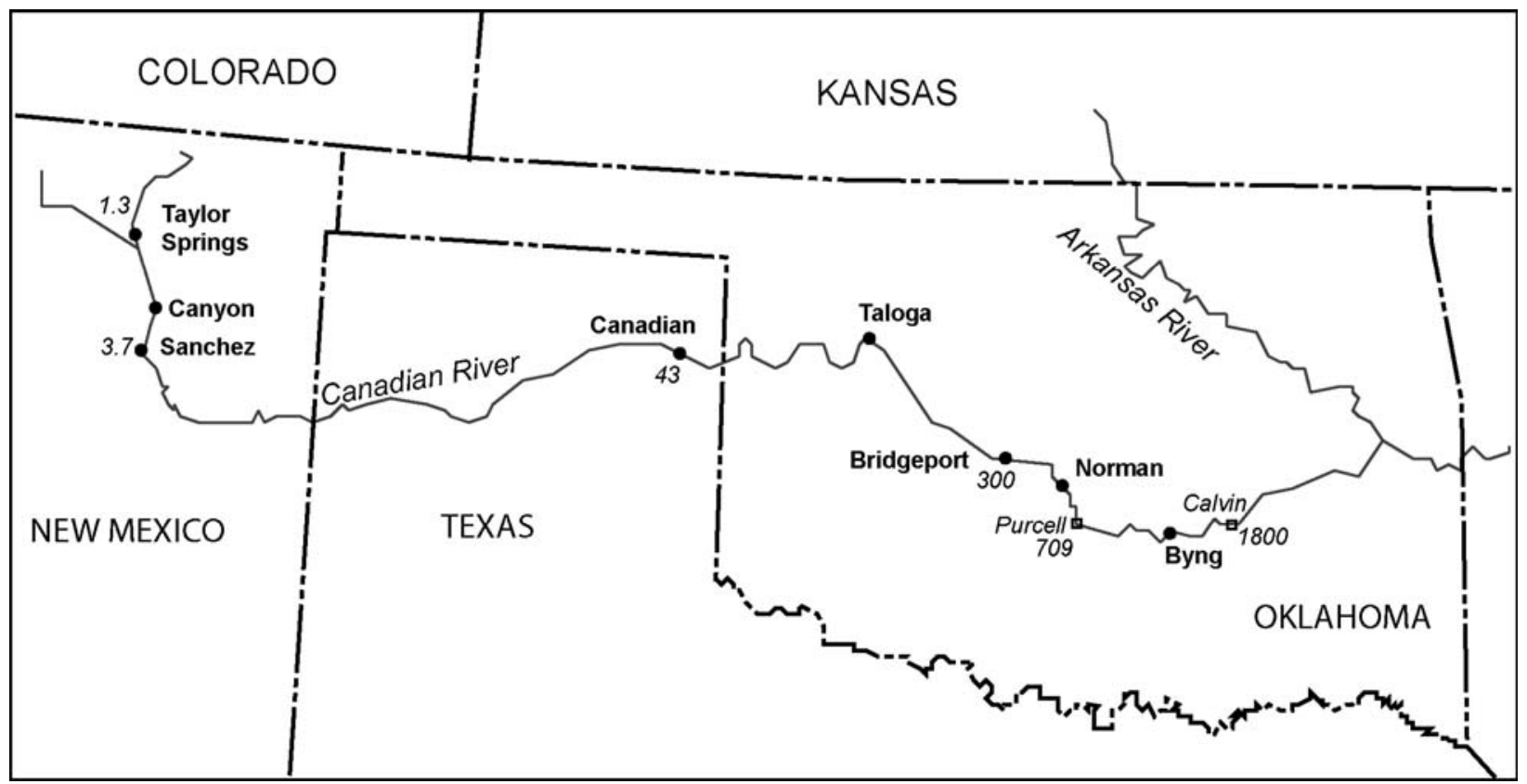

Figure 3. Map of locations of water samples collected from the Canadian River, New Mexico, Texas, and Oklahoma. Detailed coordinates are listed in table 3 . Bold font and $(\bullet)$ indicate the location of sample sites. Flow rates in the Canadian River (cubic feet per second) at the time of sampling are in italics for sample sites and the gauging stations at Purcell and Calvin, Oklahoma. Flow rates were obtained from NWIS at (http://waterdata.usgs.gov/nwis/rt).

Table 3. Time of collection and location of Canadian River water samples.

[NM, New Mexico; OK, Oklahoma; TX, Texas]

\begin{tabular}{|c|c|c|c|c|}
\hline $\begin{array}{l}\text { Sample } \\
\text { Site }\end{array}$ & Date and Time & Location Name & Latitude & Longitude \\
\hline 02CR-01 & April 21, 2002 3:14 pm & Taylor Springs, NM & N $36.35039^{\circ}$ & W $104.5725^{\circ}$ \\
\hline 02CR-02 & April 21, 2002 4:15 pm & Canyon, NM & N $36.32856^{\circ}$ & W $104.4963^{\circ}$ \\
\hline 02CR-03 & April 21, $20026: 20 \mathrm{pm}$ & Sanchez, NM & N $35.65512^{\circ}$ & W $104.3746^{\circ}$ \\
\hline 02CR-04 & April 21, 2002 12:20 pm & Norman LF, OK & $\mathrm{N} 35.16367^{\circ}$ & W $97.45332^{\circ}$ \\
\hline 02CR-05 & April 24, 2002 12:45 pm & Norman LF, proximal pond & N $35.16368^{\circ}$ & W $97.45332^{\circ}$ \\
\hline 02CR-06 & April 24, 2002 12:55 pm & Norman LF, distal pond & N $35.16370^{\circ}$ & W $97.45330^{\circ}$ \\
\hline 02CR-07 & April 24, 2002 5:03 pm & Byng, OK & N $34.93445^{\circ}$ & W $96.68255^{\circ}$ \\
\hline 02CR-08 & April 25, 2002 10:10 am & Bridgeport, OK & N $35.54023^{\circ}$ & W $98.32180^{\circ}$ \\
\hline 02CR-09 & April 25, 2002 1:10 pm & Taloaga, OK & N $36.05338^{\circ}$ & W $98.96915^{\circ}$ \\
\hline 02CR-010 & April 25, 2002 3:42 pm & Canadian, TX & N $35.93573^{\circ}$ & W $100.3703^{\circ}$ \\
\hline
\end{tabular}




\section{Sediment Analyses}

Grain size, mineralogy, iron species, sulfur species and their isotopic composition, and appearance of reactants and products were determined on the sediment samples. Sieves and a Malvern Mastersizer S long-bed laser-refraction instrument were used to determine the particle-size distribution of splits of the sediment samples. A 10-gram split of each air-dried sample was first lightly disaggregated with a mortar and pestle, manually sieved to $>$ $2 \mathrm{~mm}, 2 \mathrm{~mm}$ to $425 \mu \mathrm{m}$, and $<425 \mu \mathrm{m}$ fractions. Clay aggregates larger than $425 \mathrm{~mm}$ were visually identified and disaggregated by hand to $<425 \mu \mathrm{m}$. The mass of the three sieve fractions was measured to the nearest 0.01 gram. Approximately 0.3-gram splits of the $<425 \mu \mathrm{m}$ fraction, prepared with a mechanical splitter, were soaked overnight in distilled water amended with sodium hexametaphosphate to enhance particle dispersion. The disaggregation treatments were intended to disperse individual mineral particles. Although large intraclasts of mud and silt were visually recognized, they are not considered for this analysis. Disaggregation is compatible with the emphasis of this study on the reactivity of the sediment, which is more accurately represented by the dispersed particles. The density of measured grains were considered to be relatively similar so the weight fraction of the $>2 \mathrm{~mm}$ and $<2 \mathrm{~mm}$ to $>425 \mu \mathrm{m}$ fractions were converted to volume percent to be consistent with the results of the Mastersizer.

Bulk mineralogy of the sediments was determined by powder X-ray diffraction using a Siemens D500 with copper K-alpha radiation scanning at a count rate of 2 seconds per degree 2--theta. Clay mineralogy was determined on $<2 \mu \mathrm{m}$-size separates that were prepared by centrifugation. Oriented mounts of the $<2 \mu \mathrm{m}$-size separates were scanned as air dried, after saturating with ethylene glycol, and subsequent to heating at $550^{\circ} \mathrm{C}$ for 1 hour.

Total and organic carbon contents of the sediment were determined on raw and acid-treated aliquots. A 2gram split of the sample was combined with $20 \mathrm{~mL}$ of $2 \mathrm{~N} \mathrm{HCl}$ overnight to remove carbonate minerals. The suspension of solid and acid was filtered and rinsed thoroughly with distilled water. The total carbon and organic carbon contents of the sediment were measured by using a LECO SC-444 combustion furnace. Accuracy and precision of the carbon analyses were $\pm 5 \%$ for total carbon and $\pm 10 \%$ for organic carbon. Reported values close to the detection limit ( $0.02 \mathrm{wt} . \%$ carbon) were $\pm 20 \%$.

A JEOL JSM5800LV scanning electron microscope (SEM) equipped with an Oxford Isis energy dispersive $\mathrm{X}$-ray analyzer was used to examine 30 freeze-dried sediment samples. Disaggregated sediment was attached to a sticky carbon membrane and lightly coated with carbon and gold prior to examination and analysis. Iron and sulfur phases were the focus of the examination.

Iron speciation procedures were modified slightly from those of Heron and others (1994). Exchangeable and dissolved iron were determined by combining one of the sediment samples stored in the $50 \mathrm{~mL}$ serum vial with $40 \mathrm{~mL}$ of de-aired $1 \mathrm{~N} \mathrm{KCl}$ for 24 hours. $\mathrm{KCl}$ was used rather than the $\mathrm{CaCl}_{2}$ of Heron and others (1994) to avoid precipitation of $\mathrm{CaCO}_{3}$ given the high bicarbonate content in ground water contaminated with leachate (Cozzarelli and others, 2000). The serum vial was agitated intermittently to suspend the sediment. Following approximately 24 hours, an aliquot of solution was withdrawn by needle and syringe, and the solution was filtered using a $0.2 \mu \mathrm{m}$ filter. The solution then was analyzed for ferrous and total iron by using the spectrophotometric ferrozine method of Stookey (1970) with an ammonium acetate buffer used to maintain $\mathrm{pH}$. A second aliquot of sediment in a separate serum vial was combined with $0.5 \mathrm{~N} \mathrm{HCl}$ and reacted for 24 hours. The serum vial was intermittently shaken to suspend the sediment. Upon completion of the extraction, an aliquot of solution was removed by needle and syringe and filtered. The filtered solution was analyzed for ferrous iron by the ferrozine method (Stookey, 1970). Total iron was determined on a separate aliquot of the solution that was reacted with $2 \mathrm{~mL}$ of $1.4 \mathrm{M}$ hydroxylamine hydrochloride in $2 \mathrm{~N} \mathrm{HCl}$. After 10 minutes, the ammonium acetate buffer and ferrozine solution were added, and the concentration of total iron measured colorimetrically. Ferric iron was determined by difference between total and ferrous iron. Extraction of the reducible iron phases in the sediment was determined by using a third aliquot of the sediment and reacting it with $40 \mathrm{~mL}$ of $0.008 \mathrm{M} \mathrm{TiCl}_{3}$ in $0.05 \mathrm{M}$ EDTA, $\mathrm{pH}$ adjusted to 6.5 with $\mathrm{HCl}$. The serum vial was shaken intermittently, and the solution was withdrawn after 24 hours. The filtered $\mathrm{Ti}^{3+}$-EDTA solution was analyzed for total iron by standard methods of atomic-absorption spectrophotometry. The mass of solids was measured on the filtered residue of each extraction. This is considered a reasonable approximation of the original dry sample weight for the $\mathrm{KCl}$ and $\mathrm{Ti}^{3+}$ extractions. Results of the $0.5 \mathrm{~N} \mathrm{HCl}$ extractions of mud and intraclast samples were corrected for the mass loss because of carbonate mineral dissolution. Mass loss due to carbonate minerals in sand samples was insignificant and less than 10 percent in intraclast and silt samples. 
The abundances of acid-volatile sulfide (AVS, FeS), acid-soluble sulfate and total reducible-disulfide (DI, $\mathrm{FeS}_{2}$ ) were determined following the extraction scheme of Tuttle and others (1986). Approximately 10 to 15 grams of sediment were transferred from the frozen archive vial under a nitrogen atmosphere into a glass reaction vessel. Under flowing nitrogen, the sample was combined with $50 \mathrm{~mL}$ of $6 \mathrm{~N} \mathrm{HCl}$ and 1 gram of stannous chloride and heated to evolve $\mathrm{H}_{2} \mathrm{~S}$. The stannous chloride was added to reduce ferric iron in the samples that might oxidize evolved $\mathrm{H}_{2} \mathrm{~S}$ (Rice and others, 1993). Minor corrosion of crystallites of $\mathrm{FeS}_{2}$ following treatment of the samples with the stannous chloride and $\mathrm{HCl}$ was apparent during examination with the SEM. Based on these observations, the contribution of $\mathrm{FeS}_{2}$ to the AVS component of the samples is considered small. The evolved $\mathrm{H}_{2} \mathrm{~S}$ then was carried in flowing nitrogen through a reservoir of $\mathrm{pH} 4$ buffer to remove $\mathrm{HCl}$ and bubbled through a trap containing silver nitrate. The resulting silver sulfide was collected by filtration. After volatization of the AVS, the acid solution was separated from the solid by filtration. The solution was reacted with $10 \mathrm{~mL}$ of a 10 weight percent $\mathrm{BaCl}_{2}$ solution to precipitate dissolved sulfate as $\mathrm{BaSO}_{4}$.

The residual solid was placed in a reaction vessel under flowing nitrogen and combined with $1 \mathrm{M} \mathrm{CrCl}_{2}$ in 4 $\mathrm{N} \mathrm{HCl}$ with 10 milliliters of ethanol. Chromium (II) reduces pyritic sulfur, which is evolved as $\mathrm{H}_{2} \mathrm{~S}$. Evolved $\mathrm{H}_{2} \mathrm{~S}$ was carried through the $\mathrm{pH} 4$ buffer and then a silver nitrate solution that precipitated the $\mathrm{H}_{2} \mathrm{~S}$ as silver sulfide. The silver sulfide produced by the disulfide and AVS extractions was analyzed isotopically by direct combustion (Kester and others, 2001). Six sediment samples were mixed with acetone to extract elemental sulfur prior to AVS extraction. The resulting acetone solution was separated by filtration and treated with $\mathrm{CrCl}_{2}$ to recover the sulfur as silver sulfide. The amount of sulfur recovered by this extraction was consistently less than $0.01 \mathrm{ppm}$ and is not presented in the summary results.

\section{Water Analyses}

Major ion, trace element, dissolved organic carbon, and methane concentrations were determined on selected water samples in USGS laboratories in Reston, Virginia and Denver, Colorado. Inductively coupled plasma atomic emission spectrometry, inductively coupled plasma mass spectrometry and direct current plasma spectrometry determined the cation and trace element composition of water samples. Anions were measured with ion chromatography. Dissolved organic carbon (DOC) was measured by the method of Qian and Mopper (1996); methane was determined by the method described in Baedecker and Cozzarelli (1992).

Addition of dissolved barium chloride to selected water samples precipitated dissolved sulfate for isotope analyses. The $\mathrm{pH}$ of the water samples was adjusted between 3 and 4 with addition of $\mathrm{HCl}$ to remove dissolved carbonate species while minimizing exchange of oxygen bound to sulfate. Resulting $\mathrm{BaSO}_{4}$ was analyzed by direct combustion for sulfur and oxygen isotopes (Kester and others, 2001).

\section{Results}

\section{Sediment Composition}

The alluvium deposited by the Canadian River contains sand, silt, clay, and aggregates of fine-grained sediment forming intraclasts (table 2). Most of the samples are red as a result of the transport of hematite pigment from Permian and Triassic red beds within the drainage basin. A few samples are distinctly gray consistent with post-depositional reductive dissolution of ferric oxides. Sand samples vary from finely laminated to massive. Mixtures of silt, fine sand, and clay also tend to be massive. Intraclasts are angular to rounded and 1 to $3 \mathrm{~cm}$ in long dimension. They commonly form conglomerates that likely formed by bank collapse or during episodes of high flow. Sand intercalated with the intraclasts typically is upper medium to coarse with some granules. Results of the grain-size analysis on disaggregated sediment are presented in table 4. Sand samples are fine to medium grained and moderately to poorly sorted. Intraclast-rich samples generally have the smallest median grain size. Silt samples are mixtures of sand, silt, and clay and, according to the classification of Folk (1980), are considered mainly sandy silt (fig. 4). Silt and intraclast samples typically are very poorly sorted. Many of the silty samples were identified initially as mud during examination in the glove box because of the heavy clay texture. 
Table 4. Results of particle-size analysis of sediment samples collected by freeze-shoe coring. [Grain-size was determined on material that was disaggregated by soaking in water and sonified. Volume \%, volume percent for given size range]

\begin{tabular}{|c|c|c|c|c|c|}
\hline $\begin{array}{l}\text { Size Range } \\
\text { (micrometer) }\end{array}$ & $\begin{array}{c}\text { SG38-01 } \\
\text { (volume \%) }\end{array}$ & $\begin{array}{c}\text { SG38-02 } \\
\text { (volume \%) }\end{array}$ & $\begin{array}{c}\text { SG38-03 } \\
\text { (volume \%) }\end{array}$ & $\begin{array}{c}\text { SG38-04 } \\
\text { (volume \%) }\end{array}$ & $\begin{array}{c}\text { SG38-05 } \\
\text { (volume \%) }\end{array}$ \\
\hline$>2000$ & $<0.1$ & $<0.1$ & 0.5 & $<0.1$ & 1.0 \\
\hline 2000 to 420 & 12.1 & 10.4 & 2.7 & 3.4 & 8.5 \\
\hline 420 to 354 & 8.6 & 1.6 & 0.9 & 1.6 & 3.4 \\
\hline 354 to 297 & 11.1 & 2.3 & 1.8 & 2.5 & 4.3 \\
\hline 297 to 250 & 12.0 & 3.1 & 2.7 & 3.2 & 4.6 \\
\hline 250 to 210 & 12.0 & 3.7 & 3.6 & 3.9 & 4.7 \\
\hline 210 to 177 & 10.3 & 4.2 & 4.5 & 4.4 & 4.3 \\
\hline 177 to 149 & 9.0 & 4.4 & 5.1 & 4.9 & 4.1 \\
\hline 149 to 125 & 7.5 & 4.7 & 5.8 & 5.5 & 4.1 \\
\hline 125 to 105 & 5.8 & 5.0 & 6.5 & 5.8 & 4.0 \\
\hline 105 to 88 & 4.3 & 5.1 & 6.6 & 5.9 & 4.1 \\
\hline 88 to 74 & 2.9 & 5.2 & 6.6 & 5.7 & 4.1 \\
\hline 74 to 63 & 1.8 & 5.0 & 6.2 & 5.2 & 3.9 \\
\hline 63 to 53 & 1.2 & 4.5 & 5.4 & 5.3 & 4.2 \\
\hline 53 to 44 & 0.8 & 4.5 & 5.3 & 5.3 & 4.5 \\
\hline 44 to 37 & 0.4 & 4.5 & 5.0 & 4.4 & 4.0 \\
\hline 37 to 31.2 & 0.2 & 3.8 & 4.0 & 3.9 & 3.7 \\
\hline 31.2 to 26.3 & 0.2 & 3.4 & 3.3 & 3.5 & 3.5 \\
\hline 26.3 to 22.1 & $<0.1$ & 3.0 & 2.9 & 3.1 & 3.2 \\
\hline 22.1 to 18.6 & $<0.1$ & 2.7 & 2.5 & 2.7 & 2.9 \\
\hline 18.6 to 15.6 & $<0.1$ & 2.4 & 2.2 & 2.4 & 2.6 \\
\hline 15.6 to 13.1 & $<0.1$ & 2.1 & 1.9 & 2.1 & 2.3 \\
\hline 13.1 to 11 & $<0.1$ & 1.9 & 1.7 & 1.9 & 2.0 \\
\hline 11 to 9.3 & $<0.1$ & 1.7 & 1.5 & 1.6 & 1.7 \\
\hline 9.3 to 7.8 & $<0.1$ & 1.4 & 1.3 & 1.5 & 1.6 \\
\hline 7.8 to 6.6 & $<0.1$ & 1.3 & 1.3 & 1.3 & 1.3 \\
\hline 6.6 to 5.5 & $<0.1$ & 1.1 & 1.1 & 1.2 & 1.1 \\
\hline 5.5 to 4.6 & $<0.1$ & 1.0 & 1.0 & 1.0 & 0.9 \\
\hline 4.6 to 3.9 & $<0.1$ & 0.8 & 0.8 & 0.8 & 0.7 \\
\hline 3.9 to 3.3 & $<0.1$ & 0.6 & 0.6 & 0.7 & 0.5 \\
\hline 3.3 to 2.8 & $<0.1$ & 0.5 & 0.6 & 0.6 & 0.4 \\
\hline 2.8 to 2.3 & $<0.1$ & 0.4 & 0.5 & 0.6 & 0.4 \\
\hline 2.3 to 1.95 & $<0.1$ & 0.4 & 0.4 & 0.4 & 0.3 \\
\hline 1.95 to 1.64 & $<0.1$ & 0.3 & 0.3 & 0.3 & 0.2 \\
\hline 1.64 to 1.38 & $<0.1$ & 0.2 & 0.3 & 0.3 & 0.2 \\
\hline 1.38 to 1.16 & $<0.1$ & 0.2 & 0.2 & 0.2 & 0.2 \\
\hline 1.16 to 0.98 & $<0.1$ & 0.2 & 0.2 & 0.2 & 0.2 \\
\hline 0.98 to 0.82 & $<0.1$ & 0.1 & 0.1 & 0.2 & 0.1 \\
\hline 0.82 to 0.69 & $<0.1$ & 0.1 & 0.1 & 0.2 & 0.1 \\
\hline 0.69 to 0.58 & $<0.1$ & 0.1 & 0.1 & 0.2 & 0.1 \\
\hline 0.58 to 0.49 & $<0.1$ & 0.1 & 0.1 & 0.2 & 0.2 \\
\hline$<0.49$ & $<0.1$ & 0.2 & 0.2 & 2.2 & 1.5 \\
\hline
\end{tabular}


Table 4. Results of particle-size analysis of sediment samples collected by freeze-shoe coring - Continued

\begin{tabular}{|c|c|c|c|c|c|}
\hline $\begin{array}{l}\text { Size Range } \\
\text { (micrometer) }\end{array}$ & $\begin{array}{c}\text { SG38-06 } \\
\text { (volume \%) }\end{array}$ & $\begin{array}{c}\text { SG38-07 } \\
\text { (volume \%) }\end{array}$ & $\begin{array}{c}\text { SG38-08 } \\
\text { (volume \%) }\end{array}$ & $\begin{array}{c}\text { SG40-01 } \\
\text { (volume \%) }\end{array}$ & $\begin{array}{c}\text { SG40-02 } \\
\text { (volume \%) }\end{array}$ \\
\hline$>2000$ & 0 & 0 & 0 & 0 & 2 \\
\hline 2000 to 420 & 11.1 & 8.7 & 9.3 & 4.3 & 22.6 \\
\hline 420 to 354 & 6.8 & 3.5 & 5.3 & 2.4 & 11.3 \\
\hline 354 to 297 & 10.0 & 5.6 & 7.8 & 3.2 & 14.0 \\
\hline 297 to 250 & 12.9 & 7.8 & 9.8 & 3.6 & 13.7 \\
\hline 250 to 210 & 14.3 & 10.2 & 11.3 & 3.9 & 10.9 \\
\hline 210 to 177 & 12.9 & 11.5 & 11.1 & 4.0 & 7.9 \\
\hline 177 to 149 & 11.1 & 11.9 & 10.9 & 4.1 & 5.3 \\
\hline 149 to 125 & 8.5 & 11.7 & 9.9 & 4.2 & 3.2 \\
\hline 125 to 105 & 5.5 & 9.6 & 7.7 & 4.2 & 1.6 \\
\hline 105 to 88 & 3.1 & 6.9 & 5.5 & 4.4 & 0.7 \\
\hline 88 to 74 & 1.5 & 4.3 & 3.4 & 4.3 & 0.2 \\
\hline 74 to 63 & 0.6 & 2.3 & 1.9 & 4.0 & 0.1 \\
\hline 63 to 53 & 0.3 & 1.4 & 1.2 & 4.2 & 0.1 \\
\hline 53 to 44 & 0.1 & 0.8 & 0.7 & 4.4 & 0.2 \\
\hline 44 to 37 & $<0.1$ & 0.3 & 0.3 & 4.0 & 0.2 \\
\hline 37 to 31.2 & $<0.1$ & 0.1 & 0.2 & 3.7 & 0.3 \\
\hline 31.2 to 26.3 & 0.1 & 0.1 & 0.1 & 3.6 & 0.3 \\
\hline 26.3 to 22.1 & 0.1 & 0.1 & 0.2 & 3.4 & 0.3 \\
\hline 22.1 to 18.6 & 0.1 & 0.2 & 0.2 & 3.2 & 0.3 \\
\hline 18.6 to 15.6 & 0.1 & 0.2 & 0.2 & 3.0 & 0.3 \\
\hline 15.6 to 13.1 & 0.1 & 0.2 & 0.2 & 2.8 & 0.3 \\
\hline 13.1 to 11 & $<0.1$ & 0.2 & 0.2 & 2.5 & 0.3 \\
\hline 11 to 9.3 & $<0.1$ & 0.2 & 0.2 & 2.2 & 0.3 \\
\hline 9.3 to 7.8 & $<0.1$ & 0.2 & 0.2 & 2.1 & 0.4 \\
\hline 7.8 to 6.6 & $<0.1$ & 0.1 & 0.2 & 1.8 & 0.3 \\
\hline 6.6 to 5.5 & $<0.1$ & 0.1 & 0.2 & 1.7 & 0.3 \\
\hline 5.5 to 4.6 & $<0.1$ & 0.1 & 0.2 & 1.4 & 0.3 \\
\hline 4.6 to 3.9 & $<0.1$ & 0.1 & 0.1 & 1.1 & 0.2 \\
\hline 3.9 to 3.3 & $<0.1$ & 0.1 & 0.1 & 1.0 & 0.2 \\
\hline 3.3 to 2.8 & $<0.1$ & 0.1 & 0.1 & 0.8 & 0.2 \\
\hline 2.8 to 2.3 & $<0.1$ & 0.1 & 0.1 & 0.8 & 0.2 \\
\hline 2.3 to 1.95 & $<0.1$ & 0.1 & 0.1 & 0.5 & 0.1 \\
\hline 1.95 to 1.64 & $<0.1$ & 0.1 & 0.1 & 0.4 & 0.1 \\
\hline 1.64 to 1.38 & $<0.1$ & 0.1 & 0.1 & 0.4 & 0.1 \\
\hline 1.38 to 1.16 & $<0.1$ & 0.1 & 0.1 & 0.3 & 0.1 \\
\hline 1.16 to 0.98 & $<0.1$ & 0.1 & 0.1 & 0.2 & 0.1 \\
\hline 0.98 to 0.82 & $<0.1$ & 0.1 & 0.1 & 0.2 & 0.1 \\
\hline 0.82 to 0.69 & 0.1 & 0.1 & 0.1 & 0.2 & 0.1 \\
\hline 0.69 to 0.58 & 0.1 & 0.1 & 0.1 & 0.2 & $<0.1$ \\
\hline 0.58 to 0.49 & 0.1 & 0.1 & 0.1 & 0.2 & $<0.1$ \\
\hline$<0.49$ & 0.2 & 0.3 & 0.3 & 2.6 & $<0.1$ \\
\hline
\end{tabular}


Table 4. Results of particle-size analysis of sediment samples collected by freeze-shoe coring - Continued

\begin{tabular}{|c|c|c|c|c|c|}
\hline $\begin{array}{l}\text { Size Range } \\
\text { (micrometer) }\end{array}$ & $\begin{array}{c}\text { SG40-03 } \\
\text { (volume \%) }\end{array}$ & $\begin{array}{c}\text { SG40-04 } \\
\text { (volume \%) }\end{array}$ & $\begin{array}{c}\text { SG40-05 } \\
\text { (volume \%) }\end{array}$ & $\begin{array}{c}\text { SG40-06 } \\
\text { (volume \%) }\end{array}$ & $\begin{array}{c}\text { SG40-07 } \\
\text { (volume \%) }\end{array}$ \\
\hline$>2000$ & 0.4 & 2.7 & 2.2 & 0 & $<0.1$ \\
\hline 2000 to 420 & 1.3 & 19.6 & 10.6 & 5.5 & 1.1 \\
\hline 420 to 354 & 5.8 & 10.0 & 10.6 & 6.2 & 3.6 \\
\hline 354 to 297 & 11.5 & 12.5 & 14.5 & 10.7 & 6.1 \\
\hline 297 to 250 & 17.0 & 12.5 & 15.7 & 15.1 & 8.4 \\
\hline 250 to 210 & 18.9 & 10.1 & 13.7 & 17.5 & 10.3 \\
\hline 210 to 177 & 14.9 & 7.6 & 10.9 & 15.3 & 10.9 \\
\hline 177 to 149 & 11.1 & 5.3 & 8.1 & 12.1 & 10.4 \\
\hline 149 to 125 & 7.6 & 3.5 & 5.4 & 8.1 & 9.2 \\
\hline 125 to 105 & 4.7 & 2.1 & 3.2 & 4.5 & 7.6 \\
\hline 105 to 88 & 2.7 & 1.3 & 1.7 & 2.2 & 6.0 \\
\hline 88 to 74 & 1.4 & 0.8 & 0.7 & 1.0 & 4.5 \\
\hline 74 to 63 & 0.6 & 0.8 & 0.3 & 0.4 & 3.1 \\
\hline 63 to 53 & 0.2 & 1.2 & 0.1 & 0.1 & 2.5 \\
\hline 53 to 44 & 0.1 & 1.3 & $<0.1$ & $<0.1$ & 2.1 \\
\hline 44 to 37 & $<0.1$ & 1.3 & 0.1 & $<0.1$ & 1.5 \\
\hline 37 to 31.2 & $<0.1$ & 1.2 & 0.1 & $<0.1$ & 1.3 \\
\hline 31.2 to 26.3 & $<0.1$ & 1.0 & 0.1 & 0.1 & 1.2 \\
\hline 26.3 to 22.1 & 0.1 & 0.8 & 0.1 & 0.1 & 1.1 \\
\hline 22.1 to 18.6 & 0.1 & 0.6 & 0.1 & 0.1 & 1.0 \\
\hline 18.6 to 15.6 & 0.1 & 0.5 & 0.1 & 0.1 & 0.9 \\
\hline 15.6 to 13.1 & 0.1 & 0.4 & 0.1 & 0.1 & 0.8 \\
\hline 13.1 to 11 & $<0.1$ & 0.3 & 0.1 & 0.1 & 0.7 \\
\hline 11 to 9.3 & $<0.1$ & 0.3 & 0.1 & $<0.1$ & 0.6 \\
\hline 9.3 to 7.8 & $<0.1$ & 0.3 & 0.1 & $<0.1$ & 0.6 \\
\hline 7.8 to 6.6 & $<0.1$ & 0.2 & 0.1 & $<0.1$ & 0.5 \\
\hline 6.6 to 5.5 & $<0.1$ & 0.2 & 0.1 & 0.1 & 0.5 \\
\hline 5.5 to 4.6 & $<0.1$ & 0.2 & 0.1 & 0.1 & 0.5 \\
\hline 4.6 to 3.9 & $<0.1$ & 0.2 & 0.1 & $<0.1$ & 0.4 \\
\hline 3.9 to 3.3 & $<0.1$ & 0.1 & 0.1 & $<0.1$ & 0.3 \\
\hline 3.3 to 2.8 & $<0.1$ & 0.1 & 0.1 & $<0.1$ & 0.3 \\
\hline 2.8 to 2.3 & $<0.1$ & 0.1 & 0.1 & $<0.1$ & 0.3 \\
\hline 2.3 to 1.95 & $<0.1$ & 0.1 & 0.1 & $<0.1$ & 0.2 \\
\hline 1.95 to 1.64 & $<0.1$ & 0.1 & 0.1 & $<0.1$ & 0.2 \\
\hline 1.64 to 1.38 & $<0.1$ & 0.1 & 0.1 & 0.1 & 0.1 \\
\hline 1.38 to 1.16 & $<0.1$ & 0.1 & 0.1 & 0.1 & 0.1 \\
\hline 1.16 to 0.98 & $<0.1$ & 0.1 & 0.1 & $<0.1$ & 0.1 \\
\hline 0.98 to 0.82 & 0.1 & 0.1 & 0.1 & $<0.1$ & 0.1 \\
\hline 0.82 to 0.69 & 0.1 & $<0.1$ & 0.1 & 0.1 & 0.1 \\
\hline 0.69 to 0.58 & 0.1 & $<0.1$ & 0.1 & 0.1 & 0.1 \\
\hline 0.58 to 0.49 & 0.1 & $<0.1$ & 0.1 & 0.1 & 0.1 \\
\hline$<0.49$ & 0.3 & $<0.1$ & 0.4 & 0.2 & 0.8 \\
\hline
\end{tabular}


Table 4. Results of particle-size analysis of sediment samples collected by freeze-shoe coring - Continued

\begin{tabular}{|c|c|c|c|c|c|}
\hline $\begin{array}{l}\text { Size Range } \\
\text { (micrometer) }\end{array}$ & $\begin{array}{c}\text { SG40-08 } \\
\text { (volume \%) }\end{array}$ & $\begin{array}{c}\text { SG41-01 } \\
\text { (volume \%) }\end{array}$ & $\begin{array}{c}\text { SG41-02 } \\
\text { (volume \%) }\end{array}$ & $\begin{array}{c}\text { SG41-03 } \\
\text { (volume \%) }\end{array}$ & $\begin{array}{c}\text { SG41-04 } \\
\text { (volume \%) }\end{array}$ \\
\hline$>2000$ & $<0.1$ & 6.5 & 14.4 & 7.1 & 0.3 \\
\hline 2000 to 420 & 2.1 & 1.5 & 15.0 & 9.8 & 5.3 \\
\hline 420 to 354 & 2.0 & 5.4 & 12.8 & 10.8 & 8.6 \\
\hline 354 to 297 & 2.7 & 9.4 & 15.7 & 16.8 & 13.6 \\
\hline 297 to 250 & 3.2 & 13.5 & 14.0 & 19.4 & 17.0 \\
\hline 250 to 210 & 3.6 & 16.2 & 10.9 & 15.7 & 17.8 \\
\hline 210 to 177 & 3.8 & 14.5 & 6.9 & 9.7 & 14.1 \\
\hline 177 to 149 & 4.2 & 11.9 & 4.0 & 5.2 & 10.6 \\
\hline 149 to 125 & 4.9 & 8.7 & 2.1 & 2.6 & 6.9 \\
\hline 125 to 105 & 5.5 & 5.4 & 1.0 & 1.1 & 3.7 \\
\hline 105 to 88 & 6.1 & 3.1 & 0.4 & 0.5 & 1.7 \\
\hline 88 to 74 & 6.4 & 1.6 & 0.1 & 0.2 & 0.6 \\
\hline 74 to 63 & 6.2 & 0.7 & 0.1 & $<0.1$ & 0.2 \\
\hline 63 to 53 & 6.5 & 0.3 & $<0.1$ & $<0.1$ & 0.1 \\
\hline 53 to 44 & 6.6 & 0.1 & 0.1 & $<0.1$ & $<0.1$ \\
\hline 44 to 37 & 5.5 & $<0.1$ & 0.1 & $<0.1$ & $<0.1$ \\
\hline 37 to 31.2 & 4.6 & $<0.1$ & 0.1 & 0.1 & $<0.1$ \\
\hline 31.2 to 26.3 & 3.8 & 0.1 & 0.1 & 0.1 & $<0.1$ \\
\hline 26.3 to 22.1 & 3.1 & 0.1 & 0.1 & 0.1 & $<0.1$ \\
\hline 22.1 to 18.6 & 2.5 & 0.1 & 0.1 & $<0.1$ & $<0.1$ \\
\hline 18.6 to 15.6 & 2.1 & 0.1 & 0.1 & $<0.1$ & $<0.1$ \\
\hline 15.6 to 13.1 & 1.7 & $<0.1$ & 0.1 & $<0.1$ & $<0.1$ \\
\hline 13.1 to 11 & 1.5 & $<0.1$ & 0.1 & $<0.1$ & $<0.1$ \\
\hline 11 to 9.3 & 1.2 & $<0.1$ & 0.1 & $<0.1$ & $<0.1$ \\
\hline 9.3 to 7.8 & 1.2 & $<0.1$ & 0.1 & $<0.1$ & $<0.1$ \\
\hline 7.8 to 6.6 & 1.0 & $<0.1$ & 0.1 & $<0.1$ & $<0.1$ \\
\hline 6.6 to 5.5 & 1.0 & $<0.1$ & 0.1 & $<0.1$ & $<0.1$ \\
\hline 5.5 to 4.6 & 0.8 & $<0.1$ & 0.1 & $<0.1$ & $<0.1$ \\
\hline 4.6 to 3.9 & 0.7 & $<0.1$ & 0.1 & $<0.1$ & $<0.1$ \\
\hline 3.9 to 3.3 & 0.6 & $<0.1$ & 0.1 & $<0.1$ & $<0.1$ \\
\hline 3.3 to 2.8 & 0.5 & $<0.1$ & 0.1 & $<0.1$ & $<0.1$ \\
\hline 2.8 to 2.3 & 0.5 & $<0.1$ & 0.1 & $<0.1$ & $<0.1$ \\
\hline 2.3 to 1.95 & 0.3 & $<0.1$ & 0.1 & $<0.1$ & $<0.1$ \\
\hline 1.95 to 1.64 & 0.3 & $<0.1$ & 0.1 & $<0.1$ & $<0.1$ \\
\hline 1.64 to 1.38 & 0.3 & $<0.1$ & 0.1 & $<0.1$ & $<0.1$ \\
\hline 1.38 to 1.16 & 0.2 & 0.1 & 0.1 & $<0.1$ & $<0.1$ \\
\hline 1.16 to 0.98 & 0.2 & $<0.1$ & 0.1 & $<0.1$ & $<0.1$ \\
\hline 0.98 to 0.82 & 0.2 & 0.1 & 0.1 & $<0.1$ & $<0.1$ \\
\hline 0.82 to 0.69 & 0.2 & 0.1 & 0.1 & $<0.1$ & $<0.1$ \\
\hline 0.69 to 0.58 & 0.2 & 0.1 & 0.1 & $<0.1$ & $<0.1$ \\
\hline 0.58 to 0.49 & 0.2 & 0.1 & 0.1 & 0.1 & $<0.1$ \\
\hline$<0.49$ & 2.1 & 0.2 & 0.2 & 0.1 & $<0.1$ \\
\hline
\end{tabular}


Table 4. Results of particle-size analysis of sediment samples collected by freeze-shoe coring - Continued

\begin{tabular}{|c|c|c|c|c|c|}
\hline $\begin{array}{l}\text { Size Range } \\
\text { (micrometer) }\end{array}$ & $\begin{array}{c}\text { SG41-05 } \\
\text { (volume\%) }\end{array}$ & $\begin{array}{c}\text { SG41-06 } \\
\text { (volume \%) }\end{array}$ & $\begin{array}{c}\text { SG41-07 } \\
\text { (volume \%) }\end{array}$ & $\begin{array}{c}\text { SG41-08 } \\
\text { (volume \%) }\end{array}$ & $\begin{array}{c}\text { SG41-09 } \\
\text { (volume \%) }\end{array}$ \\
\hline$>2000$ & 2.7 & 4.7 & 3.4 & 2.2 & 3 \\
\hline 2000 to 420 & 3.9 & 2.6 & $<0.1$ & 4.9 & 13.3 \\
\hline 420 to 354 & 2.8 & 2.1 & $<0.1$ & 7.6 & 9.6 \\
\hline 354 to 297 & 3.4 & 2.7 & 0.1 & 11.4 & 15.7 \\
\hline 297 to 250 & 3.6 & 3.0 & 0.3 & 14.7 & 19.1 \\
\hline 250 to 210 & 3.5 & 3.2 & 0.6 & 16.3 & 15.8 \\
\hline 210 to 177 & 3.4 & 3.2 & 0.6 & 13.8 & 10.1 \\
\hline 177 to 149 & 3.6 & 3.4 & 0.8 & 10.8 & 5.5 \\
\hline 149 to 125 & 4.5 & 3.8 & 0.9 & 7.4 & 2.7 \\
\hline 125 to 105 & 5.6 & 4.3 & 1.2 & 4.4 & 1.2 \\
\hline 105 to 88 & 6.8 & 4.9 & 1.5 & 2.5 & 0.5 \\
\hline 88 to 74 & 7.8 & 5.4 & 1.9 & 1.3 & 0.2 \\
\hline 74 to 63 & 7.8 & 5.4 & 2.1 & 0.6 & $<0.1$ \\
\hline 63 to 53 & 8.3 & 5.9 & 2.6 & 0.3 & $<0.1$ \\
\hline 53 to 44 & 7.9 & 6.3 & 3.2 & 0.1 & 0.1 \\
\hline 44 to 37 & 5.9 & 5.5 & 3.2 & 0.1 & 0.1 \\
\hline 37 to 31.2 & 4.3 & 4.9 & 3.4 & 0.1 & 0.1 \\
\hline 31.2 to 26.3 & 3.1 & 4.3 & 3.6 & 0.1 & 0.2 \\
\hline 26.3 to 22.1 & 2.1 & 3.7 & 4.0 & 0.1 & 0.2 \\
\hline 22.1 to 18.6 & 1.4 & 3.1 & 4.3 & 0.1 & 0.2 \\
\hline 18.6 to 15.6 & 1.0 & 2.6 & 4.7 & 0.1 & 0.1 \\
\hline 15.6 to 13.1 & 0.7 & 2.2 & 5.0 & $<0.1$ & 0.1 \\
\hline 13.1 to 11 & 0.6 & 1.9 & 5.2 & $<0.1$ & 0.2 \\
\hline 11 to 9.3 & 0.5 & 1.5 & 5.2 & $<0.1$ & 0.2 \\
\hline 9.3 to 7.8 & 0.5 & 1.4 & 5.4 & $<0.1$ & 0.2 \\
\hline 7.8 to 6.6 & 0.5 & 1.1 & 4.9 & $<0.1$ & 0.2 \\
\hline 6.6 to 5.5 & 0.4 & 1.0 & 4.9 & $<0.1$ & 0.2 \\
\hline 5.5 to 4.6 & 0.4 & 0.8 & 4.2 & $<0.1$ & 0.2 \\
\hline 4.6 to 3.9 & 0.3 & 0.6 & 3.3 & $<0.1$ & 0.1 \\
\hline 3.9 to 3.3 & 0.2 & 0.5 & 2.8 & $<0.1$ & 0.1 \\
\hline 3.3 to 2.8 & 0.2 & 0.4 & 2.3 & $<0.1$ & 0.1 \\
\hline 2.8 to 2.3 & 0.2 & 0.4 & 2.2 & $<0.1$ & 0.1 \\
\hline 2.3 to 1.95 & 0.1 & 0.3 & 1.4 & $<0.1$ & 0.1 \\
\hline 1.95 to 1.64 & 0.1 & 0.2 & 1.2 & $<0.1$ & 0.1 \\
\hline 1.64 to 1.38 & 0.2 & 0.2 & 1.0 & $<0.1$ & 0.1 \\
\hline 1.38 to 1.16 & 0.2 & 0.2 & 0.8 & 0.1 & 0.1 \\
\hline 1.16 to 0.98 & 0.1 & 0.2 & 0.6 & $<0.1$ & 0.1 \\
\hline 0.98 to 0.82 & 0.1 & 0.2 & 0.6 & $<0.1$ & 0.1 \\
\hline 0.82 to 0.69 & 0.1 & 0.2 & 0.5 & 0.1 & 0.1 \\
\hline 0.69 to 0.58 & 0.1 & 0.2 & 0.5 & 0.1 & 0.1 \\
\hline 0.58 to 0.49 & 0.2 & 0.2 & 0.6 & 0.1 & 0.1 \\
\hline$<0.49$ & 0.7 & 1.3 & 4.9 & 0.3 & 0.2 \\
\hline
\end{tabular}


Table 4. Results of particle-size analysis of sediment samples collected by freeze-shoe coring - Continued

\begin{tabular}{|c|c|c|c|c|c|}
\hline $\begin{array}{l}\text { Size Range } \\
\text { (micrometer) }\end{array}$ & $\begin{array}{c}\text { SG41-10 } \\
\text { (volume \%) }\end{array}$ & $\begin{array}{l}\text { SG8802-01 } \\
\text { (volume \%) }\end{array}$ & $\begin{array}{l}\text { SG8802-02 } \\
\text { (volume \%) }\end{array}$ & $\begin{array}{l}\text { SG8802-03 } \\
\text { (volume \%) }\end{array}$ & $\begin{array}{l}\text { SG8802-05 } \\
\text { (volume \%) }\end{array}$ \\
\hline$>2000$ & 1 & 0.7 & 7.8 & 40.1 & 25.2 \\
\hline 2000 to 420 & 13.9 & 22.0 & 8.0 & 32.4 & 43.5 \\
\hline 420 to 354 & 0.6 & 11.9 & 0.5 & 3.3 & 5.3 \\
\hline 354 to 297 & 1.2 & 14.3 & 1.1 & 3.7 & 5.0 \\
\hline 297 to 250 & 1.6 & 14.1 & 1.5 & 3.3 & 4.3 \\
\hline 250 to 210 & 1.7 & 11.8 & 1.6 & 2.9 & 3.6 \\
\hline 210 to 177 & 1.4 & 9.2 & 1.4 & 2.4 & 2.8 \\
\hline 177 to 149 & 1.2 & 6.7 & 1.0 & 1.9 & 2.2 \\
\hline 149 to 125 & 0.9 & 4.5 & 0.7 & 1.5 & 1.6 \\
\hline 125 to 105 & 0.7 & 2.6 & 0.4 & 1.1 & 1.1 \\
\hline 105 to 88 & 0.7 & 1.3 & 0.3 & 0.8 & 0.7 \\
\hline 88 to 74 & 0.8 & 0.5 & 0.2 & 0.6 & 0.5 \\
\hline 74 to 63 & 0.9 & 0.2 & 0.3 & 0.4 & 0.3 \\
\hline 63 to 53 & 1.2 & 0.1 & 0.6 & 0.3 & 0.2 \\
\hline 53 to 44 & 1.7 & $<0.1$ & 1.0 & 0.3 & 0.2 \\
\hline 44 to 37 & 1.9 & $<0.1$ & 1.3 & 0.2 & 0.2 \\
\hline 37 to 31.2 & 2.2 & $<0.1$ & 1.6 & 0.2 & 0.1 \\
\hline 31.2 to 26.3 & 2.5 & $<0.1$ & 2.0 & 0.2 & 0.2 \\
\hline 26.3 to 22.1 & 3.0 & $<0.1$ & 2.4 & 0.2 & 0.2 \\
\hline 22.1 to 18.6 & 3.4 & $<0.1$ & 2.7 & 0.2 & 0.2 \\
\hline 18.6 to 15.6 & 3.9 & $<0.1$ & 2.9 & 0.2 & 0.2 \\
\hline 15.6 to 13.1 & 4.4 & $<0.1$ & 2.9 & 0.2 & 0.2 \\
\hline 13.1 to 11 & 4.7 & $<0.1$ & 3.0 & 0.2 & 0.2 \\
\hline 11 to 9.3 & 4.8 & $<0.1$ & 3.0 & 0.2 & 0.2 \\
\hline 9.3 to 7.8 & 5.1 & $<0.1$ & 3.2 & 0.2 & 0.2 \\
\hline 7.8 to 6.6 & 4.8 & $<0.1$ & 3.1 & 0.2 & 0.2 \\
\hline 6.6 to 5.5 & 4.9 & $<0.1$ & 3.5 & 0.2 & 0.2 \\
\hline 5.5 to 4.6 & 4.3 & $<0.1$ & 3.5 & 0.2 & 0.2 \\
\hline 4.6 to 3.9 & 3.5 & $<0.1$ & 3.2 & 0.2 & 0.1 \\
\hline 3.9 to 3.3 & 2.9 & $<0.1$ & 3.2 & 0.2 & 0.1 \\
\hline 3.3 to 2.8 & 2.4 & $<0.1$ & 3.1 & 0.2 & 0.1 \\
\hline 2.8 to 2.3 & 2.2 & $<0.1$ & 3.5 & 0.2 & 0.1 \\
\hline 2.3 to 1.95 & 1.4 & $<0.1$ & 2.8 & 0.2 & 0.1 \\
\hline 1.95 to 1.64 & 1.2 & $<0.1$ & 2.6 & 0.2 & 0.1 \\
\hline 1.64 to 1.38 & 0.9 & $<0.1$ & 2.3 & 0.1 & 0.1 \\
\hline 1.38 to 1.16 & 0.7 & $<0.1$ & 2.0 & 0.1 & 0.1 \\
\hline 1.16 to 0.98 & 0.5 & $<0.1$ & 1.7 & 0.1 & $<0.1$ \\
\hline 0.98 to 0.82 & 0.5 & $<0.1$ & 1.5 & 0.1 & $<0.1$ \\
\hline 0.82 to 0.69 & 0.4 & $<0.1$ & 1.3 & 0.1 & $<0.1$ \\
\hline 0.69 to 0.58 & 0.4 & $<0.1$ & 1.2 & 0.1 & $<0.1$ \\
\hline 0.58 to 0.49 & 0.4 & $<0.1$ & 1.1 & 0.1 & $<0.1$ \\
\hline$<0.49$ & 3.3 & $<0.1$ & 9.0 & 0.4 & 0.2 \\
\hline
\end{tabular}


Table 4. Results of particle-size analysis of sediment samples collected by freeze-shoe coring - Continued

\begin{tabular}{|c|c|c|c|c|c|}
\hline $\begin{array}{l}\text { Size Range } \\
\text { (micrometer) }\end{array}$ & $\begin{array}{l}\text { SG8802-06 } \\
\text { (volume \%) }\end{array}$ & $\begin{array}{l}\text { SG8802-07 } \\
\text { (volume \%) }\end{array}$ & $\begin{array}{l}\text { SG8803-01 } \\
\text { (volume \%) }\end{array}$ & $\begin{array}{l}\text { SG8803-03 } \\
\text { (volume \%) }\end{array}$ & $\begin{array}{c}\text { SG99-01 } \\
\text { (volume \%) }\end{array}$ \\
\hline$>2000$ & 0 & 2.1 & $<0.1$ & $<0.1$ & 0.5 \\
\hline 2000 to 420 & 3.3 & 9.4 & 2.4 & 27.3 & 20.5 \\
\hline 420 to 354 & 1.7 & 2.4 & 0.3 & 15.3 & 12.7 \\
\hline 354 to 297 & 2.3 & 2.6 & 0.5 & 17.2 & 15.5 \\
\hline 297 to 250 & 2.6 & 2.5 & 0.7 & 14.1 & 14.1 \\
\hline 250 to 210 & 2.7 & 2.4 & 0.7 & 10.8 & 12.3 \\
\hline 210 to 177 & 2.5 & 2.1 & 0.9 & 7.1 & 9.4 \\
\hline 177 to 149 & 2.4 & 2.0 & 1.3 & 4.3 & 6.7 \\
\hline 149 to 125 & 2.5 & 2.1 & 2.1 & 2.3 & 4.3 \\
\hline 125 to 105 & 2.8 & 2.3 & 3.2 & 1.0 & 2.4 \\
\hline 105 to 88 & 3.4 & 2.8 & 4.5 & 0.4 & 1.2 \\
\hline 88 to 74 & 3.9 & 3.2 & 5.6 & 0.1 & 0.5 \\
\hline 74 to 63 & 4.0 & 3.4 & 6.0 & $<0.1$ & 0.2 \\
\hline 63 to 53 & 4.6 & 4.0 & 6.9 & $<0.1$ & 0.1 \\
\hline 53 to 44 & 5.1 & 4.6 & 7.3 & $<0.1$ & $<0.1$ \\
\hline 44 to 37 & 4.8 & 4.4 & 6.3 & $<0.1$ & $<0.1$ \\
\hline 37 to 31.2 & 4.6 & 4.4 & 5.7 & $<0.1$ & $<0.1$ \\
\hline 31.2 to 26.3 & 4.4 & 4.4 & 5.2 & $<0.1$ & $<0.1$ \\
\hline 26.3 to 22.1 & 4.2 & 4.3 & 4.7 & $<0.1$ & $<0.1$ \\
\hline 22.1 to 18.6 & 4.0 & 4.1 & 4.2 & $<0.1$ & $<0.1$ \\
\hline 18.6 to 15.6 & 3.8 & 4.0 & 3.8 & $<0.1$ & $<0.1$ \\
\hline 15.6 to 13.1 & 3.6 & 3.7 & 3.4 & $<0.1$ & $<0.1$ \\
\hline 13.1 to 11 & 3.5 & 3.4 & 3.1 & $<0.1$ & $<0.1$ \\
\hline 11 to 9.3 & 3.1 & 3.0 & 2.8 & $<0.1$ & $<0.1$ \\
\hline 9.3 to 7.8 & 3.0 & 2.9 & 2.6 & $<0.1$ & $<0.1$ \\
\hline 7.8 to 6.6 & 2.6 & 2.4 & 2.2 & $<0.1$ & $<0.1$ \\
\hline 6.6 to 5.5 & 2.5 & 2.2 & 2.1 & $<0.1$ & $<0.1$ \\
\hline 5.5 to 4.6 & 2.0 & 1.8 & 1.7 & $<0.1$ & $<0.1$ \\
\hline 4.6 to 3.9 & 1.5 & 1.4 & 1.3 & $<0.1$ & $<0.1$ \\
\hline 3.9 to 3.3 & 1.3 & 1.2 & 1.1 & $<0.1$ & $<0.1$ \\
\hline 3.3 to 2.8 & 1.0 & 0.9 & 0.8 & $<0.1$ & $<0.1$ \\
\hline 2.8 to 2.3 & 0.9 & 0.9 & 0.8 & $<0.1$ & $<0.1$ \\
\hline 2.3 to 1.95 & 0.6 & 0.6 & 0.5 & $<0.1$ & $<0.1$ \\
\hline 1.95 to 1.64 & 0.5 & 0.5 & 0.4 & $<0.1$ & $<0.1$ \\
\hline 1.64 to 1.38 & 0.4 & 0.4 & 0.4 & $<0.1$ & $<0.1$ \\
\hline 1.38 to 1.16 & 0.3 & 0.3 & 0.3 & $<0.1$ & $<0.1$ \\
\hline 1.16 to 0.98 & 0.3 & 0.2 & 0.3 & $<0.1$ & $<0.1$ \\
\hline 0.98 to 0.82 & 0.2 & 0.2 & 0.2 & $<0.1$ & $<0.1$ \\
\hline 0.82 to 0.69 & 0.2 & 0.2 & 0.2 & $<0.1$ & $<0.1$ \\
\hline 0.69 to 0.58 & 0.2 & 0.2 & 0.2 & $<0.1$ & $<0.1$ \\
\hline 0.58 to 0.49 & 0.2 & 0.2 & 0.3 & $<0.1$ & $<0.1$ \\
\hline$<0.49$ & 2.5 & 1.7 & 2.8 & $<0.1$ & $<0.1$ \\
\hline
\end{tabular}


Table 4. Results of particle-size analysis of sediment samples collected by freeze-shoe coring - Continued

\begin{tabular}{|c|c|c|c|c|}
\hline $\begin{array}{l}\text { Size Range } \\
\text { (micrometer) }\end{array}$ & $\begin{array}{c}\text { SG99-1r } \\
\text { (volume \%) }\end{array}$ & $\begin{array}{c}\text { SG99-02 } \\
\text { (volume \%) }\end{array}$ & $\begin{array}{c}\text { SG99-03 } \\
\text { (volume \%) }\end{array}$ & $\begin{array}{c}\text { SG99-04 } \\
\text { (volume \%) }\end{array}$ \\
\hline$>2000$ & 1.0 & $<0.1$ & 2.0 & $<0.1$ \\
\hline 2000 to 420 & 18.8 & 21.5 & 5.9 & 2.1 \\
\hline 420 to 354 & 13.2 & 12.6 & 1.4 & 6.3 \\
\hline 354 to 297 & 17.1 & 17.3 & 2.0 & 11.3 \\
\hline 297 to 250 & 15.6 & 16.6 & 2.3 & 15.3 \\
\hline 250 to 210 & 12.6 & 13.4 & 2.5 & 17.5 \\
\hline 210 to 177 & 8.5 & 8.4 & 2.5 & 15.8 \\
\hline 177 to 149 & 5.4 & 4.7 & 2.6 & 12.1 \\
\hline 149 to 125 & 3.1 & 2.5 & 2.9 & 8.8 \\
\hline 125 to 105 & 1.6 & 1.2 & 3.3 & 5.5 \\
\hline 105 to 88 & 0.7 & 0.5 & 4.0 & 3.1 \\
\hline 88 to 74 & 0.3 & 0.2 & 4.7 & 1.4 \\
\hline 74 to 63 & 0.1 & 0.1 & 5.0 & 0.5 \\
\hline 63 to 53 & $<0.1$ & $<0.1$ & 6.0 & 0.2 \\
\hline 53 to 44 & 0.1 & 0.1 & 6.8 & 0.1 \\
\hline 44 to 37 & 0.1 & 0.1 & 6.4 & $<0.1$ \\
\hline 37 to 31.2 & 0.1 & 0.1 & 6.0 & $<0.1$ \\
\hline 31.2 to 26.3 & 0.1 & 0.1 & 5.4 & $<0.1$ \\
\hline 26.3 to 22.1 & 0.1 & 0.1 & 4.7 & $<0.1$ \\
\hline 22.1 to 18.6 & 0.1 & $<0.1$ & 3.9 & $<0.1$ \\
\hline 18.6 to 15.6 & 0.1 & $<0.1$ & 3.2 & $<0.1$ \\
\hline 15.6 to 13.1 & 0.1 & $<0.1$ & 2.5 & $<0.1$ \\
\hline 13.1 to 11 & 0.1 & $<0.1$ & 2.0 & $<0.1$ \\
\hline 11 to 9.3 & 0.1 & $<0.1$ & 1.6 & $<0.1$ \\
\hline 9.3 to 7.8 & 0.1 & $<0.1$ & 1.4 & $<0.1$ \\
\hline 7.8 to 6.6 & 0.1 & $<0.1$ & 1.1 & $<0.1$ \\
\hline 6.6 to 5.5 & 0.1 & $<0.1$ & 1.1 & $<0.1$ \\
\hline 5.5 to 4.6 & 0.1 & $<0.1$ & 0.9 & $<0.1$ \\
\hline 4.6 to 3.9 & 0.1 & $<0.1$ & 0.7 & $<0.1$ \\
\hline 3.9 to 3.3 & 0.1 & $<0.1$ & 0.6 & $<0.1$ \\
\hline 3.3 to 2.8 & 0.1 & $<0.1$ & 0.5 & $<0.1$ \\
\hline 2.8 to 2.3 & 0.1 & $<0.1$ & 0.5 & $<0.1$ \\
\hline 2.3 to 1.95 & $<0.1$ & $<0.1$ & 0.3 & $<0.1$ \\
\hline 1.95 to 1.64 & 0.1 & $<0.1$ & 0.3 & $<0.1$ \\
\hline 1.64 to 1.38 & 0.1 & $<0.1$ & 0.3 & $<0.1$ \\
\hline 1.38 to 1.16 & 0.1 & $<0.1$ & 0.2 & $<0.1$ \\
\hline 1.16 to 0.98 & $<0.1$ & $<0.1$ & 0.2 & $<0.1$ \\
\hline 0.98 to 0.82 & $<0.1$ & $<0.1$ & 0.2 & $<0.1$ \\
\hline 0.82 to 0.69 & $<0.1$ & $<0.1$ & 0.2 & $<0.1$ \\
\hline 0.69 to 0.58 & $<0.1$ & $<0.1$ & 0.2 & $<0.1$ \\
\hline 0.58 to 0.49 & $<0.1$ & $<0.1$ & 0.2 & $<0.1$ \\
\hline$<0.49$ & 0.2 & 0.1 & 1.7 & $<0.1$ \\
\hline
\end{tabular}




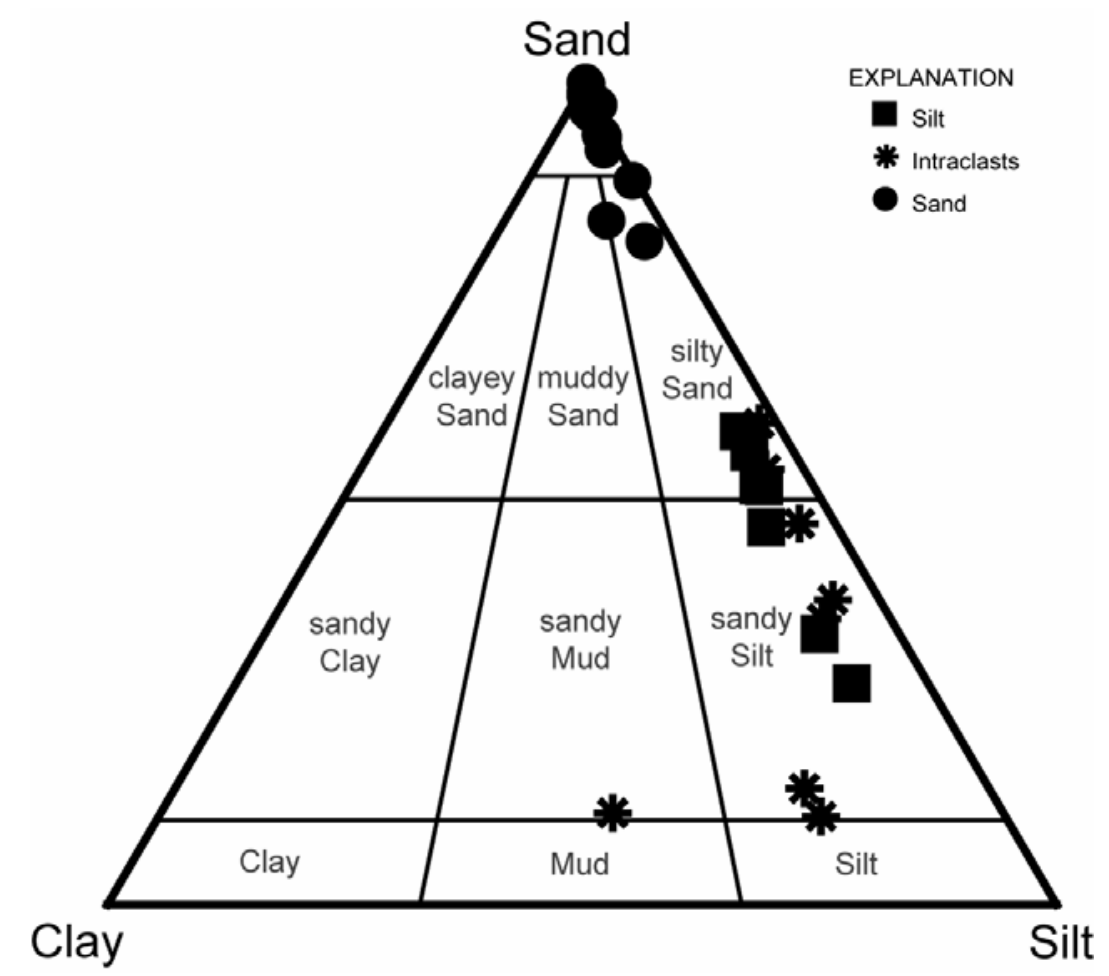

Figure 4. Ternary diagram of the relative abundance of sand, silt, and clay in samples collected by freeze-shoe coring from the alluvium of the Canadian River near Norman, Oklahoma.

Detrital constituents of the Canadian River alluvium include quartz, plagioclase, potassium feldspar, calcite, dolomite, and clay minerals. Silts are differentiated mineralogically from sands by increased abundances of clay and calcite. Clay minerals detected include illite-smectite, illite, smectite, kaolinite, and chlorite. Common heavy minerals that were identified include magnetite, hematite, sphene, and garnet consistent with the results of Pollack (1961).

Examination of the sediment samples with the SEM identified pyrite, barite and very fine $(<0.1 \mu \mathrm{m})$ ferric oxides as well as the major minerals described above. Pyrite is present in nearly all samples. Pyrite textures include framboids formed by anhedral aggregates (fig. 5), framboids with euhedral constituent grains, massive pyrite aggregates (fig. 6$)$ and large (>10 $\mu \mathrm{m})$ crystals, some with spiral overgrowths (fig. 7). Crystallite aggregates that form framboids in shallow samples are typically pseudo cubic to subhedral (fig. 5) while deeper samples have well formed octahedral faces. Textures of barite are consistent with detrital and authigenic grains (fig. 8). Several of the detrital barite grains have delicate textures that are would not have survived transport. The delicate textures are attributed to in situ dissolution. Although the sediment is pervasively red, isolated grains of iron oxide responsible for the pigment were not resolvable at $0.1 \mu \mathrm{m}$. Efforts to isolate red particles on sand grain surfaces consistently detected iron-rich clay particles and not the discrete iron oxides expected. The particles of hematite responsible for the red color could not be resolved at the resolution of the SEM $(<50 \mathrm{~nm})$.

Table 5 lists the results of the iron analyses. Variations in the abundance of extractable iron are related to grain size with muds and mud clasts having greater amounts of leachable iron than sands. Only small amounts of exchangable and soluble iron were extracted with $1 \mathrm{~N} \mathrm{KCl}$ in a few silt and intraclast samples. Iron soluble in $0.5 \mathrm{~N}$ $\mathrm{HCl}$ is largely ferrous iron and is approximately 10 times more abundant in silt and intraclast samples than sand samples. Ferric iron was determined to be the dominant component of acid extractable iron only in modern river sand. Core samples with detectable ferric iron include a few silt samples and all samples from SG99. 


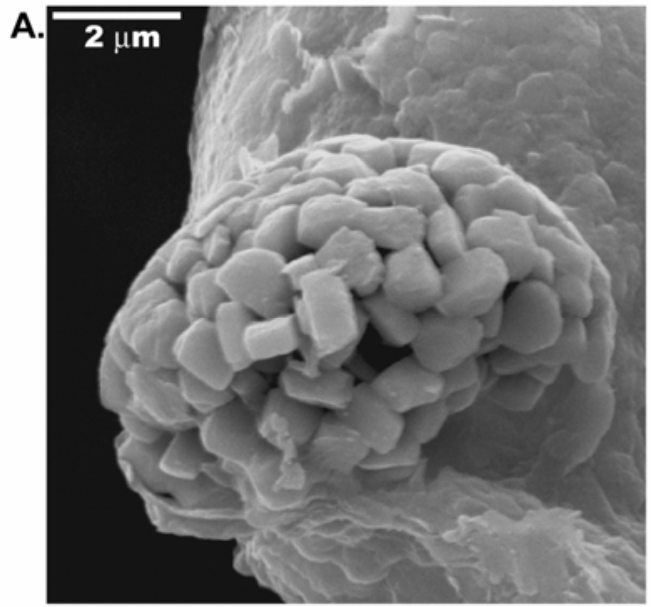

B.

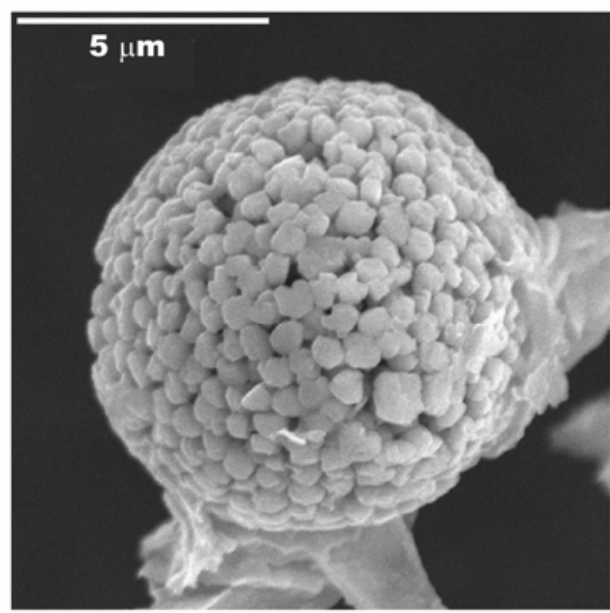

C.

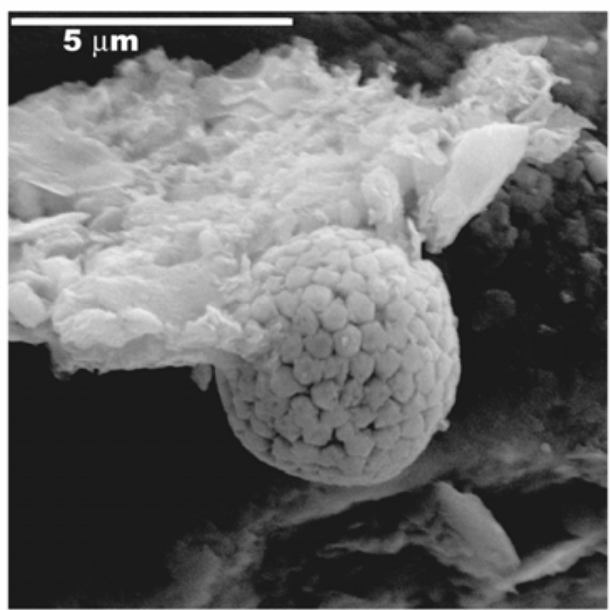

D.

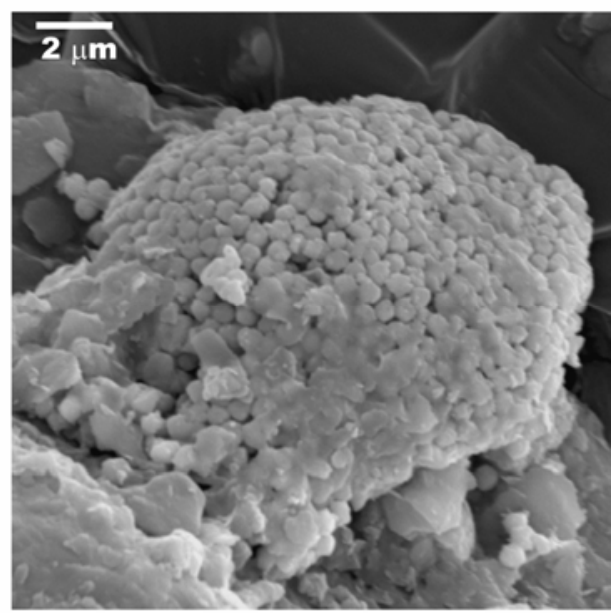

E.

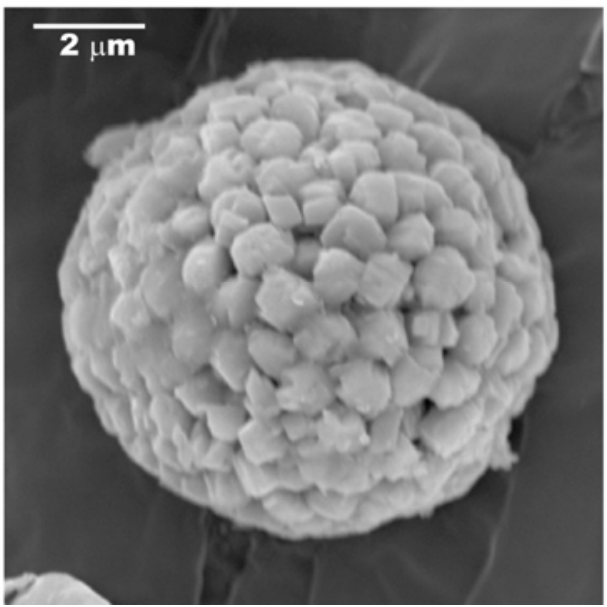

F.

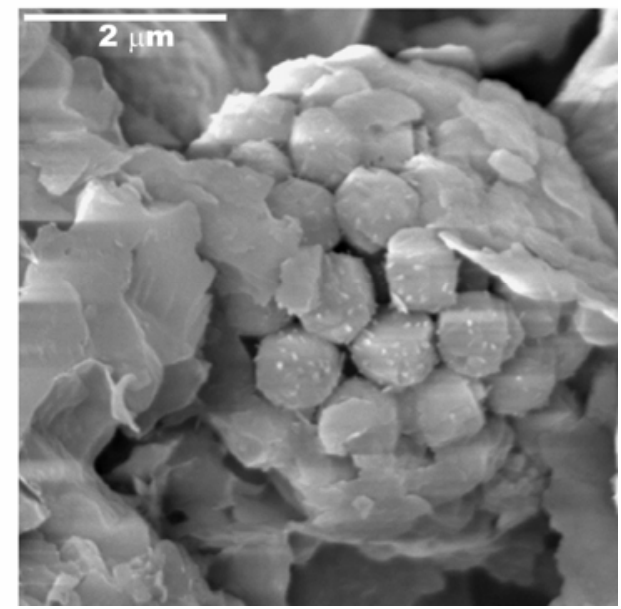

Figure 5. Secondary electron micrograph images of pyrite from relatively shallow samples ( $<2$ meters) within the Canadian River alluvium. Note the irregular shape and surface of pyrite crystallites forming framboids and other aggregates. ( $A, B$, and $C$ ) pyrite aggregates in black sand from the slough sediment. ( $D, E$, and $F$ ) pyrite aggregates associated with clays from a black layer near water table at 5 feet depth in core VCA. 
A.

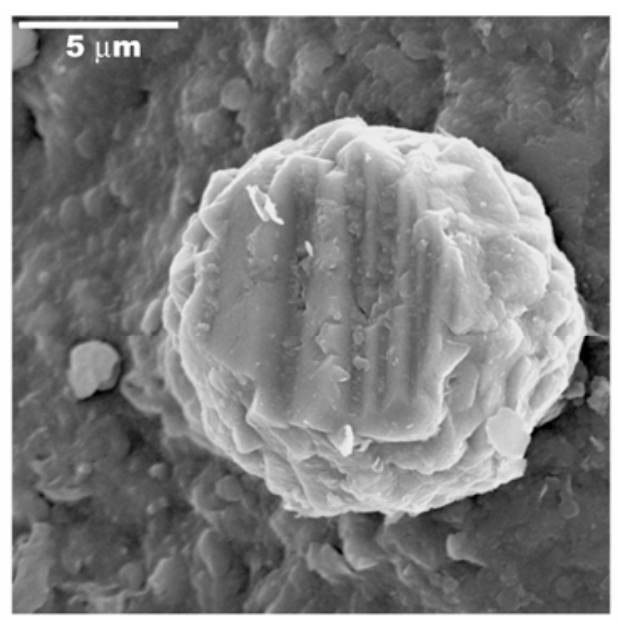

C.

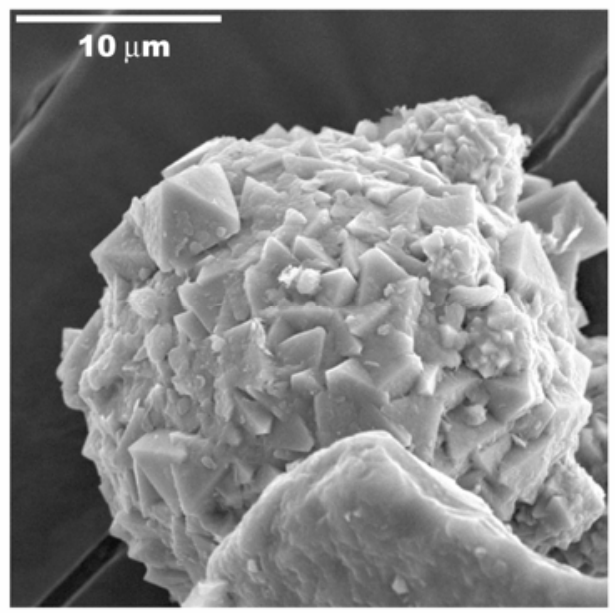

E.

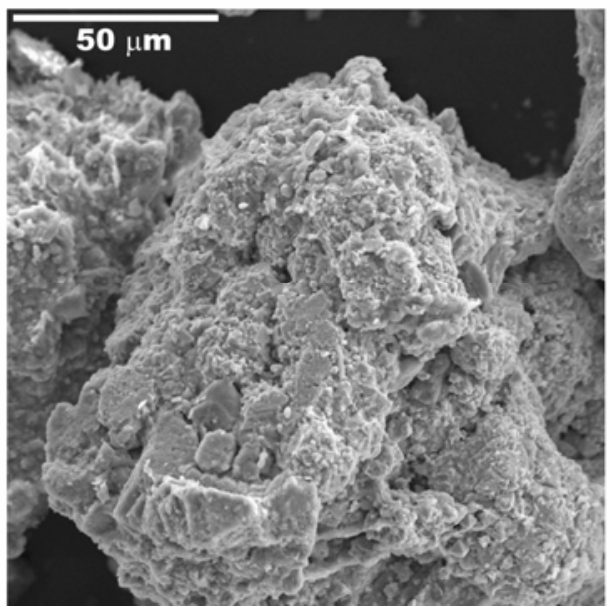

B.

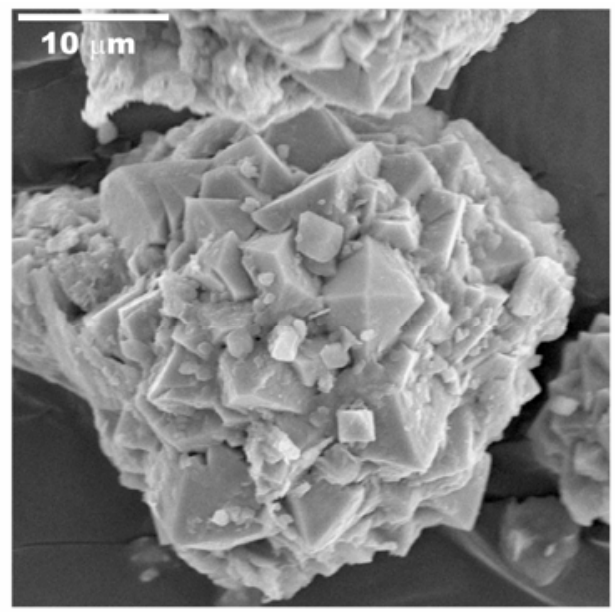

D.

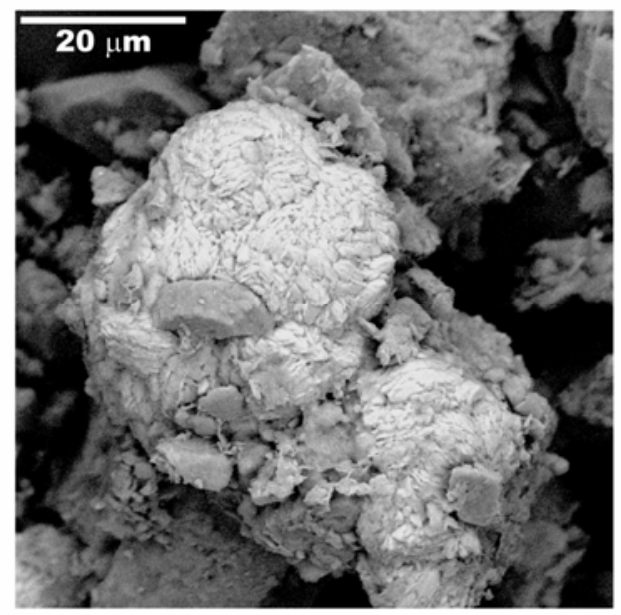

F.

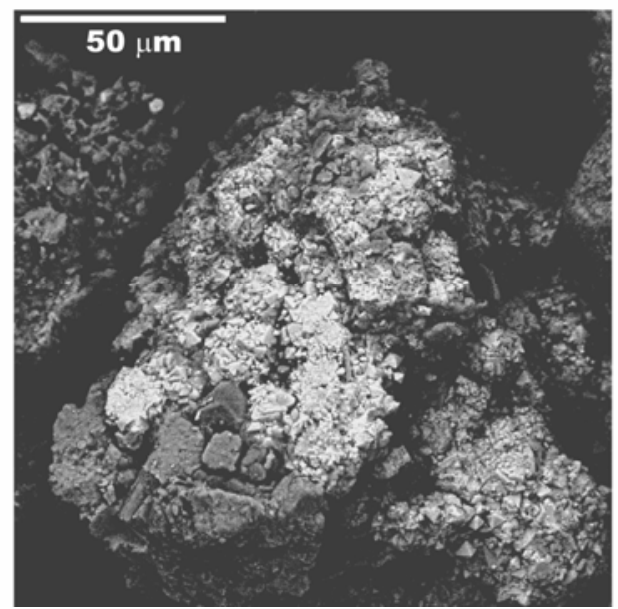

Figure 6. Secondary electron and backscatter micrographs of massive pyrite aggregates from sediment samples of the Canadian River alluvium. (A) SG99-02, secondary electron micrograph of pyrite aggregate with poor crystal outline may be corroded or possibly reworked with sediment, (B) SG88-02-01, secondary electron micrograph of pyrite formed by aggregate of octahedral crystals, (C) SG41-04, secondary electron micrograph of an aggregate of octahedral pyrite crystals, (D) backscatter electron micrograph of pyrite (bright field) with quartz and clay, (E) secondary electron micrograph, and (F) backscatter electron micrograph of a large grain composed mainly of pyrite. 
A.

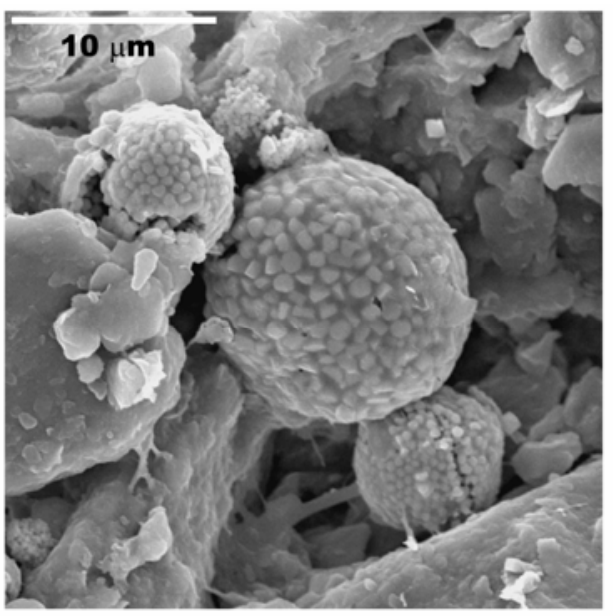

C.

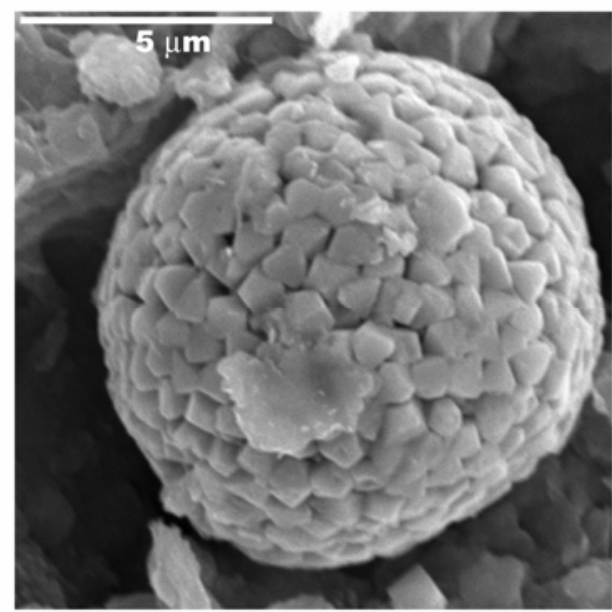

E.

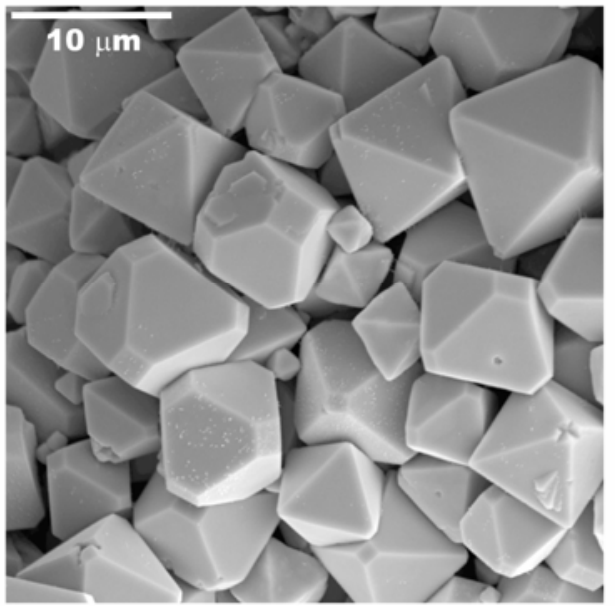

B.

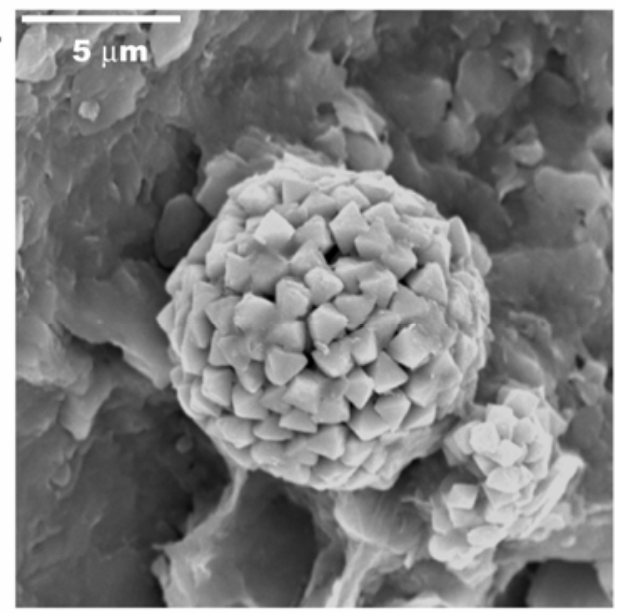

D.

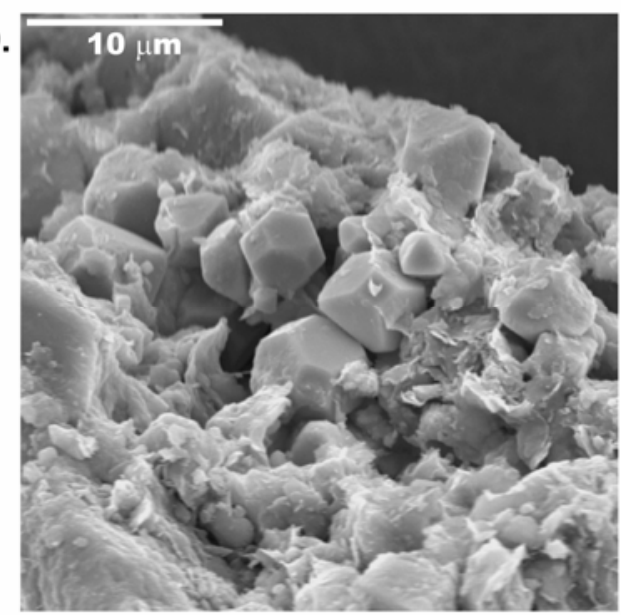

F.

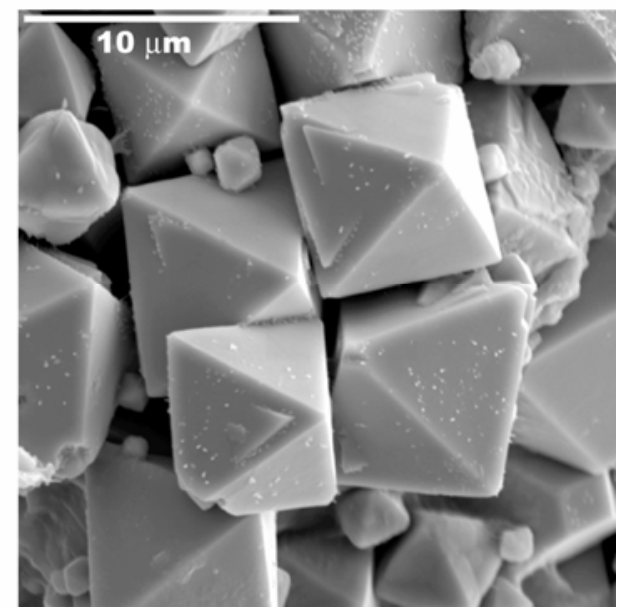

Figure 7. Secondary electron images of well-formed pyrite crystals from samples of the Canadian River alluvium below depths of 2 meters. (A) SG88-02-07, pyrite framboid coated with biophage?, (B) SG99-03, pyrite framboid on clay, (C) SG41-04, (D) SG99-03, truncated octahedral pyrite in clay, (E,F) SG88-03-01, coarse pyrite with spiral overgrowths formed in vertical open space about $1 \mathrm{~mm}$ in diameter crossing red mud. 
A.

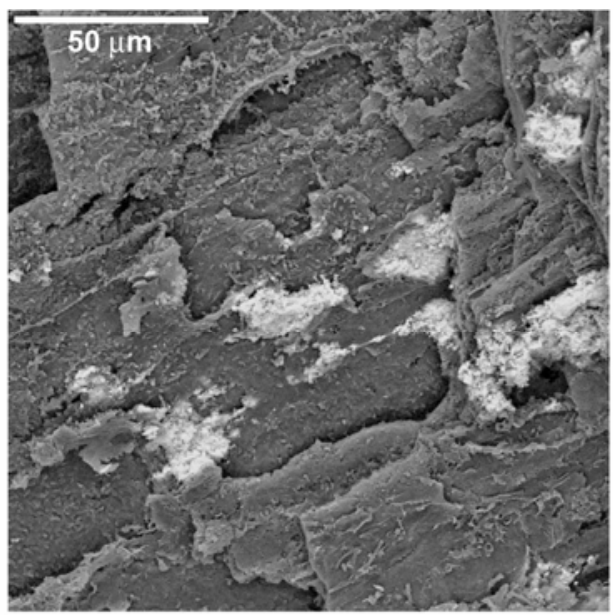

C.

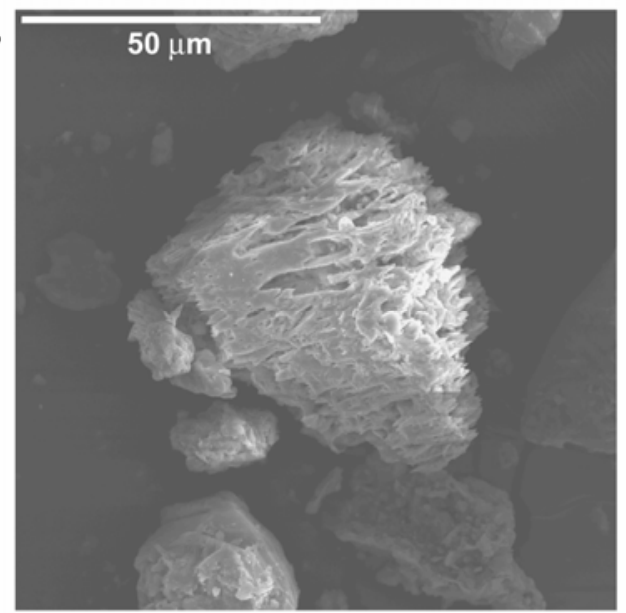

E.

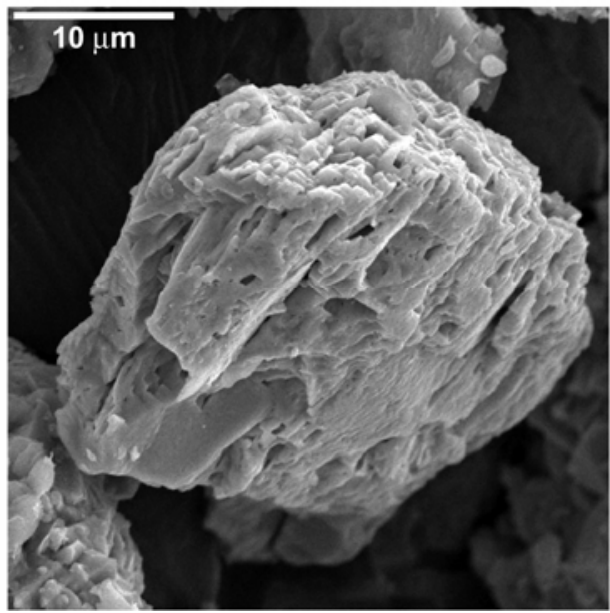

B.

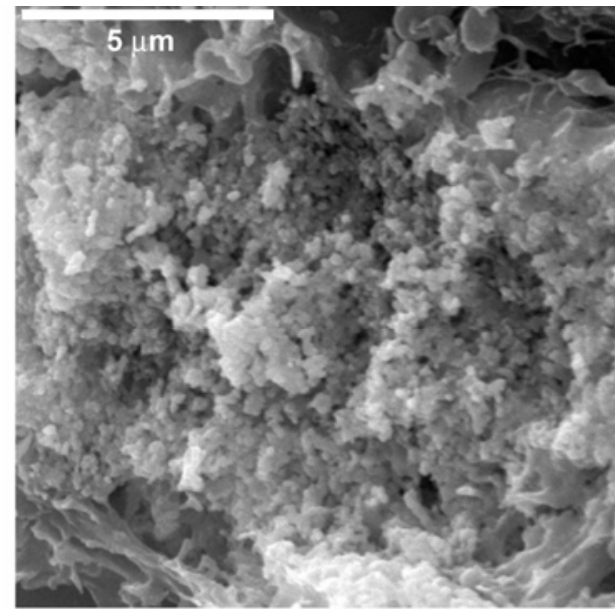

D.

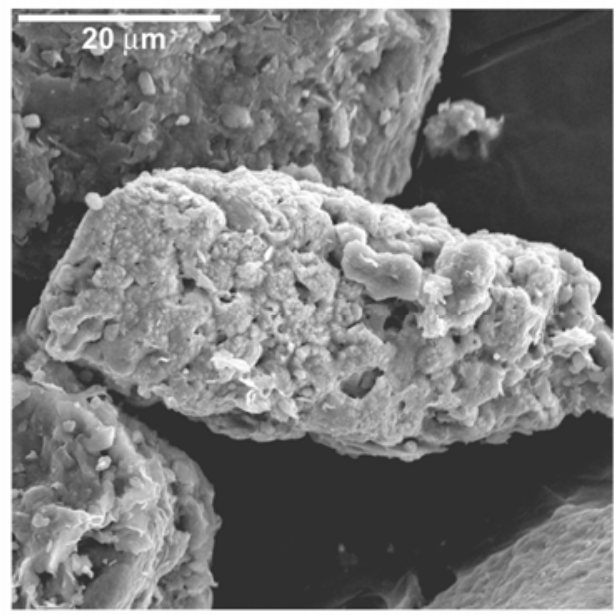

F.

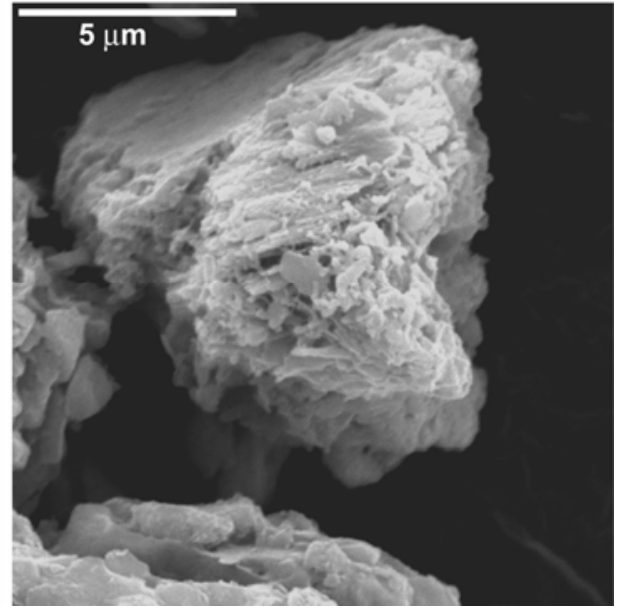

Figure 8. Micrographs of barite detected within the Canadian River alluvium. Micrographs are obtained with a scanning electron microscope. (A) backscatter electron image and (B) secondary electron image of authigenic barite growing on woody fragment from SG38-04, (C) secondary electron image of corroded detrital barite VCA, 17 feet depth, (D) SG40-06, partially corroded detrital barite grain, (E) secondary electron image of relatively unaltered detrital barite from SG-88-07, (F) secondary electron image of partially dissolved barite grain from slough sediment. 
Table 5. Concentrations of iron extracted from sediment samples by treatment with $1 \mathrm{~N} \mathrm{KCl}, 0.5 \mathrm{M} \mathrm{HCl}$ and $\mathrm{Ti}^{3+}$ EDTA for 24 hours.

[Each extraction was done on a separate aliquot of sediment. Results expressed as parts per million (ppm) of the sediment. ---, not determined].

\begin{tabular}{|c|c|c|c|c|c|}
\hline $\begin{array}{l}\text { Sample } \\
\text { Number }\end{array}$ & $\begin{array}{l}1 \mathrm{~N} \mathrm{KCl} \mathrm{Fe}^{2+} \\
\mathrm{Fe}^{2+}(\mathrm{ppm})\end{array}$ & $\begin{array}{c}0.5 \mathrm{M} \mathrm{HCl} \\
\mathrm{Fe}^{2+}(\mathrm{ppm})\end{array}$ & $\begin{array}{c}0.5 \mathrm{M} \mathrm{HCl} \\
\text { Total Iron (ppm) }\end{array}$ & $\begin{array}{c}0.5 \mathrm{M} \mathrm{HCl} \\
\mathrm{Fe}^{3+}(\mathrm{ppm})\end{array}$ & $\begin{array}{c}\mathrm{Ti}^{3+}-\text { EDTA } \\
\text { Total Iron (ppm) }\end{array}$ \\
\hline SG38-01 & $<0.2$ & 270 & 260 & $<20$ & 430 \\
\hline SG38-02 & $<0.2$ & 2250 & 2250 & $<50$ & 3800 \\
\hline SG38-03 & 0.54 & 4300 & 4100 & $<100$ & 4600 \\
\hline SG38-04 & 5.3 & 1700 & 1700 & $<100$ & 1600 \\
\hline SG38-05 & $<0.2$ & 1200 & 1200 & $<50$ & 1700 \\
\hline SG38-06 & $<0.2$ & 190 & 170 & $<20$ & 500 \\
\hline SG38-07 & $<0.2$ & 330 & 340 & $<20$ & 600 \\
\hline SG38-08 & $<0.2$ & 260 & 260 & $<20$ & 510 \\
\hline SG40-01 & $<0.2$ & 3000 & 3250 & $<100$ & 6800 \\
\hline SG40-02 & $<0.2$ & 290 & 290 & $<20$ & 410 \\
\hline SG40-03 & $<0.2$ & 220 & 210 & $<20$ & 340 \\
\hline SG40-04 & $<0.2$ & 250 & 250 & $<20$ & 380 \\
\hline SG40-05 & $<0.2$ & 250 & 230 & $<20$ & 400 \\
\hline SG40-06 & $<0.2$ & --- & --- & --- & 440 \\
\hline SG40-07 & 0.47 & 4600 & 4700 & $<100$ & 2200 \\
\hline SG40-08 & 5.3 & 2750 & 2650 & $<100$ & 1600 \\
\hline SG41-01 & $<0.2$ & 210 & --- & -- & 720 \\
\hline SG41-02 & $<0.2$ & 260 & 510 & 250 & 480 \\
\hline SG41-03 & $<0.2$ & -- & --- & --- & 490 \\
\hline SG41-04 & $<0.2$ & 360 & 380 & 20 & 740 \\
\hline SG41-05 & 0.70 & 1150 & 1150 & $<50$ & 1800 \\
\hline SG41-06 & $<0.2$ & 1600 & 1550 & $<50$ & 2000 \\
\hline SG41-07 & 29 & 3250 & 3150 & $<100$ & 460 \\
\hline SG41-08 & $<0.2$ & 270 & 270 & $<20$ & 720 \\
\hline $\begin{array}{l}\text { SG41-09 } \\
\end{array}$ & $<0.2$ & 280 & 280 & $<20$ & 500 \\
\hline SG41-10 & 4 & 2150 & 2150 & $<50$ & 1100 \\
\hline SG88-02-01 & --- & 140 & 140 & $<20$ & $\mathrm{NA}$ \\
\hline SG88-02-02 & $<0.2$ & 860 & 860 & $<50$ & 53 \\
\hline SG88-02-03 & --- & 220 & 220 & $<20$ & 48 \\
\hline SG88-02-05 & $<0.2$ & 180 & 180 & $<20$ & 510 \\
\hline SG88-02-06 & $<0.2$ & 2200 & 2200 & $<100$ & 1300 \\
\hline SG88-02-07 & 18 & 2050 & 2050 & $<100$ & 1200 \\
\hline SG88-03-01 & $<0.2$ & 1750 & 1900 & 200 & 1600 \\
\hline SG88-03-03 & $<0.2$ & 120 & 120 & $<20$ & 230 \\
\hline SG99-01 & $<0.2$ & 60 & 100 & 40 & 240 \\
\hline SG99-02 & $<0.2$ & 110 & 140 & 30 & 260 \\
\hline SG99-03 & 0.20 & 1250 & 1600 & 400 & 1300 \\
\hline SG99-04 & $<0.2$ & 120 & 160 & 40 & 270 \\
\hline ACRS-02d & $-\cdots$ & 50 & 130 & 80 & 620 \\
\hline ACRS-02e & $-\cdots$ & 50 & 130 & 80 & 680 \\
\hline MLS32 & --- & -- & --- & $-\cdots$ & --- \\
\hline MLS81 & --- & $-\cdots$ & --- & $-\cdots$ & --- \\
\hline
\end{tabular}


$\mathrm{The}^{\mathrm{3+}} \mathrm{Ti}^{\mathrm{r}}$ reductive dissolution of iron oxides in 24 hours was variably effective at dissolution of red ferric oxides. Following 24 hours of exposure to the reagent, all pink-red sand samples had visually changed to gray. Red-brown silt and intraclast samples, however, remained largely red brown. The color of the $\mathrm{Ti}^{3+}$ solution in contact with the mud after 24 hours remained distinctly pink indicating that the $\mathrm{Ti}^{3+}$ had not been consumed. Allowing the suspended clay to settle revealed a stratification in which the last settled particles (smallest size fraction) were distinctly gray while the coarser fragments were red brown. Solutions were nonetheless extracted and analyzed according to the 24-hour reaction time recommended by Heron and others (1994). The $\mathrm{Ti}^{3+}$ and clay suspensions were allowed to react for 18 additional months after which time the color of the solution became pale yellow for the silt and intraclast samples but remained pink for sand samples. Most of the mud remained red even after 18 months, although the portion of gray sediment increased. The incomplete and slow reductive dissolution of ferric oxides in the silt and intraclast samples is attributed to a diffusion limited reduction reaction of ferric oxides intercalated with clay particles and insufficient $\mathrm{Ti}^{3+}$ to complete the reduction.

Sulfur is present in the Canadian River alluvium as acid-soluble sulfate, acid-volatile sulfides (FeS), and chromium reducible sulfide $\left(\mathrm{FeS}_{2}\right.$ ) (table 6). Gray sediment accumulates 2 to 4 times more sulfur than red-brown sediment, with gray mud accumulating more than gray sand. Red sand on the surface contains the least amount of sulfur. Samples having the highest concentrations of pyrite and sulfate are intraclasts from uncontaminated core. The highest acid-volatile sulfur concentrations are from intraclasts and sands from the uncontaminated core. The sulfur isotopic compositions of these phases generally are higher in samples from contaminated core, likely reflecting greater reduction of the sulfate reservoir with increased dissolved organic compounds contained in the leachate. Silt and intraclast samples contain about twice the amount of sulfate as sands; however, the sulfate from the sands has negative sulfur isotopic compositions, suggesting the sulfate extracted from the sand is a product of oxidation of bacterially reduced sulfide.

\section{Water Composition}

The composition of pore water and ground water follow the pattern of compositions outlined in Cozzarelli and others (2000) (tables 7 and 8). Concentrations of alkalinity, ammonium, iron, arsenic, barium, boron, calcium, chloride, cobalt, DOC, lithium, magnesium, methane, nickel, potassium, rubidium, and selenium decline with increasing distance from the landfill. Sulfate is the only constituent that increases as the river is approached. The concentrations of ammonium, arsenic, boron, cobalt, and potassium in pore water from SG41 are intermediate to values characteristic of highly impacted (SG38 and SG40) and background sites (SG88 and SG99). Other parameters such as alkalinity, calcium, iron, magnesium, and strontium are consistent with substantial leachate contamination. The intermediate concentrations of several constituents in ground water recovered from SG41 are consistent with either leachate of a slightly different composition or the recent increase of the leachate component to ground water at SG41 as described by Becker (2002). As the leachate advances through the alluvium, some constituents are removed from solution by cation exchange and absorption. The sulfur isotopic composition of the ground water and surface water is highly variable. Systematic changes of composition with sulfate abundance, however, indicate that bacterial sulfate reduction is an active process in the Canadian River alluvium independent of the landfill leachate.

The Canadian River water composition changes slightly along its course from northeastern New Mexico to east-central Oklahoma (table 9). Some of the variations may be related to the three man-made reservoirs located on the river prior to its entry into Oklahoma. Specific conductance generally declines downstream reflecting the addition of dilute recharge eastward through Oklahoma. The increased recharge is apparent in the increased flow of the river (fig. 3). Samples of two small surface depressions containing stagnant water (table 2) near the active channel of the Canadian River were also sampled. Water in both the proximal pond ( $1 \mathrm{~m}$ from the active channel, 02-CR-05) and distal pond (10 $\mathrm{m}$ from the active channel, 02-CR-06) have markedly lower specific conductance than river water (02-CR-04) (table 9). The lower specific conductance of the ponds is attributed to rainwater recharge of the alluvium.

The sulfur isotope composition of dissolved sulfate in the river is distinctly different between northeastern New Mexico and Oklahoma. The supply of sulfate in New Mexico is attributed to the oxidation of biogenic sulfide minerals in Cretaceous rock exposed in the drainage basin. In northern Texas and Oklahoma, the principal source of sulfate is gypsum exposed in Permian rocks along the drainage. 
Table 6. Content of organic carbon, forms of sulfur, and sulfur isotopic compositions of sediment samples.

$\left[\mathrm{S}_{\mathrm{SO} 4}\right.$ - acid soluble sulfate, $\mathrm{S}_{\mathrm{AV}}$-acid-volatile sulfur; $\mathrm{S}_{\mathrm{DI}}$ - disulfide sulfur (pyrite+maracasite); $\Sigma_{\text {sulfide, }}$ sum of $\mathrm{S}_{\mathrm{av}}$ and $\mathrm{S}_{\mathrm{dil}}$; insuff, insufficient material for analysis; ---, not determined; wt.\%, weight percent; $\mu \mathrm{mol} / \mathrm{g}$, micromole per gram of sediment; \%o, per mil, for sulfur isotopes reported relative to Canon Diablo Troilite]

\begin{tabular}{|c|c|c|c|c|c|c|c|c|c|c|}
\hline Sample & $\begin{array}{l}\mathrm{C}_{\text {organic }} \\
\text { (wt.\%) }\end{array}$ & $\begin{array}{c}S_{\text {total }} \\
\text { (wt.\%) }\end{array}$ & $\begin{array}{c}\mathrm{S}_{\mathrm{SO} 4} \\
(\mu \mathrm{mol} / \mathrm{g})\end{array}$ & $\begin{array}{c}\delta^{34} \mathrm{~S}_{\mathrm{SO} 4} \\
\% \text { oo }\end{array}$ & $\begin{array}{c}S_{A V} \\
(\mu \mathrm{mol} / \mathrm{g})\end{array}$ & $\begin{array}{c}\delta^{34} \mathrm{~S}_{\mathrm{AV}} \\
\% \text { oo }\end{array}$ & $\begin{array}{c}\mathrm{S}_{\mathrm{DI}} \\
(\mu \mathrm{mol} / \mathrm{g})\end{array}$ & $\begin{array}{c}\delta^{34} S_{D I} \\
\%\end{array}$ & $\begin{array}{c}\Sigma_{\text {sulfide }} \\
(\mu \mathrm{mol} / \mathrm{g})\end{array}$ & $\begin{array}{c}\delta^{34} S_{\text {sulfide }} \\
\% \text { oo }\end{array}$ \\
\hline SG38-01 & $<0.05$ & 0.007 & $<0.3$ & insuff & 1.9 & -3.4 & 0.21 & -0.5 & 2.1 & -3.0 \\
\hline SG38-02 & 0.27 & 0.083 & 8.7 & -3.0 & 9.7 & -1.8 & 7.5 & -12.9 & 17 & -6.6 \\
\hline SG38-03 & 0.36 & 0.10 & $<0.3$ & insuff & 3.4 & -13.1 & 29 & -16.8 & 32 & -16.4 \\
\hline SG38-04 & 0.46 & 0.38 & 10 & -0.7 & 41 & 5.4 & 69 & -4.9 & 110 & -1.1 \\
\hline SG38-05 & 0.17 & 0.14 & 5.3 & -4.5 & 12 & 4.6 & 25 & -3.6 & 37 & -0.9 \\
\hline SG38-06 & $<0.05$ & 0.042 & 2.0 & -4.9 & 7.5 & 12.7 & 3.7 & -1.8 & 11 & 7.9 \\
\hline SG38-07 & 0.16 & 0.078 & 6.5 & -14.1 & 7.8 & 2.8 & 10 & -11.7 & 18 & -5.3 \\
\hline SG40-01 & 0.37 & 0.22 & 3.4 & 8.2 & 11 & -22.6 & 53 & -24.7 & 64 & -24.3 \\
\hline SG40-02 & $<0.05$ & 0.068 & $<0.3$ & insuff & 6.5 & 2.4 & 15 & -3.1 & 21 & -1.4 \\
\hline SG40-03 & $<0.05$ & 0.025 & 0.16 & insuff & 6.2 & 0.6 & 1.2 & -10.2 & 7.4 & -1.2 \\
\hline SG40-04 & $<0.05$ & 0.022 & 0.34 & insuff & 3.4 & -0.3 & 3.1 & -3.9 & 6.5 & -2.0 \\
\hline SG40-05 & $<0.05$ & 0.018 & $<0.3$ & insuff & 3.7 & -6.6 & 1.9 & -19.6 & 5.6 & -10.9 \\
\hline SG40-06 & $<0.05$ & 0.012 & $<0.3$ & insuff & 1.6 & 3.5 & 2.2 & 12.4 & 3.8 & 8.7 \\
\hline SG40-07 & 0.25 & 0.021 & 4.4 & 13.8 & 0.22 & insuff & 1.9 & 11.5 & 2.1 & 11.5 \\
\hline SG40-08 & 0.32 & 0.018 & 2.2 & 10.3 & 1.9 & insuff & 1.9 & insuff & 3.8 & insuff \\
\hline SG41-01 & $<0.05$ & 0.029 & 0.44 & -- & 1.7 & insuff & 7.0 & --- & 8.7 & -- \\
\hline SG41-04 & $<0.05$ & 0.027 & 0.22 & -- & 1.9 & -9.6 & 6.9 & -9.3 & 8.8 & -9.4 \\
\hline SG41-05 & 0.10 & 0.038 & $<0.3$ & insuff & 5.8 & -21.1 & 5.9 & -28.9 & 12 & -25.0 \\
\hline SG41-07 & 0.18 & 0.032 & $<0.3$ & insuff & 5.2 & -15.0 & 4.7 & -23.0 & 9.9 & -18.8 \\
\hline SG41-08 & $<0.05$ & 0.018 & 2.1 & --- & 1.8 & insuff & 1.7 & insuff & 3.5 & insuff \\
\hline SG41-10 & 0.39 & 0.070 & 4.1 & 10.4 & 3.7 & -13.7 & 14 & -12.8 & 18 & -13.0 \\
\hline
\end{tabular}


Table 6. Content of organic carbon, forms of sulfur, and sulfur isotopic compositions of sediment samples—Continued

\begin{tabular}{|c|c|c|c|c|c|c|c|c|c|c|}
\hline Sample & $\begin{array}{l}\text { Corganic } \\
\text { (wt. \%) }\end{array}$ & $\begin{array}{c}S_{\text {total }} \\
\text { (wt. \%) }\end{array}$ & $\begin{array}{c}\mathrm{S}_{\mathrm{SO} 4} \\
(\mu \mathrm{mol} / \mathrm{g})\end{array}$ & $\begin{array}{c}\delta^{34} \mathrm{~S}_{\mathrm{SO} 4} \\
\%\end{array}$ & $\begin{array}{c}S_{A V} \\
(\mu \mathrm{mol} / \mathrm{g})\end{array}$ & $\begin{array}{c}\delta^{34} S_{A V} \\
\% \text { oo }\end{array}$ & $\begin{array}{c}S_{D I} \\
(\mu \mathrm{mol} / \mathrm{g})\end{array}$ & $\begin{array}{l}\delta^{34} \mathrm{~S}_{\mathrm{DI}} \\
\% \\
\%\end{array}$ & $\begin{array}{c}\sum_{\text {sulfide }} \\
(\mu \mathrm{mol} / \mathrm{g})\end{array}$ & $\begin{array}{c}\delta^{34} \mathrm{~S} \text { sulfide } \\
\% \text { oo }\end{array}$ \\
\hline SG88-02-01 & $<0.05$ & 0.58 & 11 & -19 & 100 & -22.1 & 69 & -22.6 & 169 & -22.3 \\
\hline SG88-02-02 & 0.31 & 1.0 & 10 & -10.7 & 120 & -14.8 & 185 & -16.1 & 305 & -15.6 \\
\hline SG88-02-03 & $<0.05$ & 0.56 & 5.6 & -12.3 & 105 & -14.8 & 64 & -18.1 & 169 & -16.1 \\
\hline SG88-02-04 & $<0.05$ & 0.24 & 5.0 & -3.0 & 36 & -19.9 & 35 & -19.8 & 71 & -19.9 \\
\hline SG88-02-05 & 0.12 & 0.11 & 1.9 & -3.6 & 25 & -18.4 & 8.4 & -16.4 & 33 & -17.9 \\
\hline SG88-02-07 & 0.52 & 0.076 & 13 & -0.8 & 3.7 & -5.3 & 7.6 & -4.1 & 11 & -4.5 \\
\hline SG88-03-01 & 0.35 & 0.027 & $<0.3$ & insuff & 2.7 & 5.4 & 5.6 & 3.1 & 8.3 & 3.9 \\
\hline SG88-03-02 & $<0.05$ & 0.031 & 2.5 & 11.0 & 0.94 & -12.6 & 6.2 & -16.0 & 7.1 & -15.6 \\
\hline SG88-03-03 & $<0.05$ & 0.044 & $<0.3$ & insuff & 2.2 & -10.3 & 0.31 & -18.4 & 2.5 & -11.3 \\
\hline SG99-01 & $<0.05$ & 0.057 & $<0.3$ & insuff & 2.5 & -10.4 & 0.94 & -17.5 & 3.4 & -12.3 \\
\hline SG99-02 & $<0.05$ & 0.059 & $<0.3$ & insuff & 2.2 & -7.4 & 3.4 & -9.4 & 5.6 & -8.6 \\
\hline SG99-03 & 0.48 & 0.20 & 2.8 & 9.0 & 13 & -15.0 & 28 & -24.1 & 41 & -21.2 \\
\hline SG99-04 & $<0 . .05$ & 0.03 & $<0.3$ & insuff & 8.4 & 5.4 & 0.31 & insuff & 8.7 & 5.4 \\
\hline Slough Sed.-99a & --- & --- & 3.4 & --- & 5.0 & -3.7 & 1.9 & 4.4 & 6.2 & -1.3 \\
\hline Slough Sed.-99b & --- & --- & 6.9 & --- & 70 & 1.8 & 1.2 & 3.6 & 74 & 1.2 \\
\hline Slough Sed.-99c & --- & --- & --- & --- & 12 & 7.4 & 1.2 & 3.6 & 13 & 7.2 \\
\hline ACRS-99 & -- & --- & --- & --- & 1.2 & -15.9 & --- & --- & --- & --- \\
\hline ACRS-00a & -- & 0.77 & $<0.3$ & insuff & 0.37 & -10.9 & 0.31 & -16.5 & 0.68 & -14.8 \\
\hline ACRS-00b & --- & 0.019 & 1.8 & 11.7 & 1.4 & -6.2 & 2.8 & -11.7 & 4.2 & -10.0 \\
\hline ACRS-02a & --- & --- & --- & --- & 0.94 & -7.1 & 1.6 & -12.2 & 2.5 & -10.3 \\
\hline $\begin{array}{l}\text { CRS-02b (proximal } \\
\text { pond) }\end{array}$ & --- & --- & --- & --- & 2.2 & 2.1 & 2.5 & -13.3 & 4.7 & -5.0 \\
\hline $\begin{array}{l}\text { ACRS-02c (distal } \\
\text { pond) }\end{array}$ & --- & --- & --- & --- & 1.6 & -2.3 & 1.9 & -11.1 & 3.4 & -7.3 \\
\hline $\begin{array}{l}\text { ACRS-02d (active } \\
\text { bar) }\end{array}$ & --- & --- & --- & --- & --- & --- & 0.34 & -16 & --- & --- \\
\hline $\begin{array}{l}\text { ACRS-02e (river } \\
\text { bank) }\end{array}$ & --- & --- & --- & --- & --- & --- & 0.34 & -17.8 & --- & --- \\
\hline MLS32 & --- & --- & 1.2 & 8.3 & 4.0 & -0.6 & 1.7 & -12.9 & 5.7 & 0.4 \\
\hline MLS81 & --- & --- & 0.97 & 11.8 & 4.6 & --- & 2.9 & 2.9 & 7.5 & --- \\
\hline
\end{tabular}


Table 7. Chemical composition of pore water withdrawn directly from core of the Canadian River alluvium that was obtained by freeze-shoe coring.

[mg/L, milligrams/liter; $\mu \mathrm{g} / \mathrm{L}$, microgram/liter; DOC, dissolved organic carbon; ---, not determined]

\begin{tabular}{|c|c|c|c|c|c|c|c|c|c|c|c|}
\hline Sample & $\begin{array}{c}\text { Elevation of } \\
\text { extraction point } \\
\text { (meter) }\end{array}$ & $\mathrm{pH}$ & $\begin{array}{c}\text { Alkalinity }^{1} \\
\text { (mg/L) }\end{array}$ & $\begin{array}{c}\text { Ammonia }^{a} \\
(\mathrm{mg} / \mathrm{L})\end{array}$ & $\begin{array}{l}\mathrm{Fe}^{2+4} \\
(\mathrm{mg} / \mathrm{L})\end{array}$ & $\begin{array}{c}\text { Methane }{ }^{2} \\
(\mathrm{mg} / \mathrm{L})\end{array}$ & $\begin{array}{l}\mathrm{DOC}^{3} \\
(\mathrm{mg} / \mathrm{L})\end{array}$ & $\begin{array}{c}\mathrm{Al}^{5} \\
(\mu \mathrm{g} / \mathrm{L})\end{array}$ & $\begin{array}{c}\mathrm{As}^{5} \\
(\mu \mathrm{g} / \mathrm{L})\end{array}$ & $\begin{array}{c}B^{5} \\
(\mu g / L)\end{array}$ & $\begin{array}{c}\mathrm{Ba}^{5} \\
(\mu \mathrm{g} / \mathrm{L})\end{array}$ \\
\hline SG38-a & 327.8 & 6.95 & 2330 & 295 & 11 & 1.6 & 84 & 90 & 9 & 5070 & 7020 \\
\hline SG38-b & 327.6 & --- & -- & 60 & 5.8 & 2.0 & --- & 60 & 9 & 4470 & 7250 \\
\hline SG38-c & 326.85 & --- & --- & 225 & 3.5 & --- & --- & 60 & 36 & 4610 & 4540 \\
\hline SG40-a & 327.52 & 7.06 & 3080 & 280 & 4.6 & 11 & 155 & 50 & 16 & 5670 & 7260 \\
\hline SG40-b & 327.3 & 7.40 & 2850 & 260 & 9.8 & 7.4 & --. & 20 & 18 & 5620 & 8740 \\
\hline SG40-c & 326.75 & 6.79 & 2580 & 300 & 15 & 11 & 120 & 20 & 12 & 4880 & 6920 \\
\hline SG40-d & 326.25 & 6.82 & 1730 & 145 & 5.2 & 4.2 & 105 & 20 & 14 & 3400 & 3280 \\
\hline SG41-a & 326.3 & 6.86 & 2170 & 145 & 13 & 0.11 & 70 & 30 & 9 & 2460 & 898 \\
\hline SG41-b & 326 & 6.93 & 1880 & 140 & 4.3 & 0.12 & 58 & 60 & 7 & 1570 & 1160 \\
\hline SG41-c & 325.7 & 6.85 & 1720 & 70 & 3.8 & 0.093 & 48 & 20 & 6 & 1480 & 1040 \\
\hline SG41-d & 325.4 & 6.92 & 1720 & 85 & 7.8 & --- & 42 & 420 & 7 & 1450 & 900 \\
\hline SG41-e & 325.1 & 6.96 & 1680 & 100 & 6.9 & --- & 200 & 20 & 9 & 1330 & 863 \\
\hline SG41-f & 324.95 & -- & -- & 15 & 7.5 & -- & --- & 20 & 7 & 1590 & 769 \\
\hline SG41-g & 324.85 & 7.11 & 950 & -- & 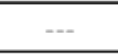 & -- & $\ldots$ & -- & $-\cdots$ & $-\cdots$ & -- \\
\hline SG88-02-a & 326.4 & --- & --- & --- & 0.25 & --- & -- & -- & --- & --- & --- \\
\hline SG88-02-b & 326.27 & 7.51 & 640 & --- & 0.063 & -- & -- & 10 & 2 & 780 & 406 \\
\hline SG88-03-a & 327.72 & 7.00 & --- & --- & 1.4 & -- & -- & -- & -- & --- & --- \\
\hline SG88-03-b & 327.48 & 7.73 & 710 & -- & 0.28 & -- & 13 & 10 & 4 & 500 & 1520 \\
\hline SG88-03-c & 327.1 & 7.33 & 665 & 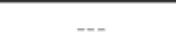 & 0.24 & -- & 13 & 20 & 2 & 630 & 390 \\
\hline SG99-a & 326.4 & 7.19 & 445 & 3.0 & 0.75 & 0.12 & 9.9 & 10 & 2 & 50 & 671 \\
\hline SG99-b & 325.7 & 7.36 & 395 & 0.20 & 2.0 & 0.017 & 3.6 & 210 & 1 & 89 & 1240 \\
\hline SG99-c & 325.4 & 7.82 & --- & 21 & --- & --- & -- & 50 & 6 & 120 & 1450 \\
\hline SG99-d & 325.08 & --- & -- & 6.4 & 0.10 & --- & -- & 50 & 1 & 89 & 1320 \\
\hline
\end{tabular}

See footnotes at end of table 
Table 7. Chemical composition of pore water withdrawn directly from core of the Canadian River alluvium that was obtained by freeze-shoe coring - Continued

\begin{tabular}{|c|c|c|c|c|c|c|c|c|c|c|c|c|}
\hline Sample & $\begin{array}{c}\mathrm{Ca}^{6} \\
(\mathrm{mg} / \mathrm{L})\end{array}$ & $\begin{array}{c}\mathrm{Co}^{5} \\
(\mu \mathrm{g} / \mathrm{L})\end{array}$ & $\begin{array}{c}\mathrm{Cu}^{5} \\
(\mu \mathrm{g} / \mathrm{L})\end{array}$ & $\begin{array}{c}\mathrm{K}^{6} \\
(\mathrm{mg} / \mathrm{L})\end{array}$ & $\begin{array}{c}\mathrm{Li}^{5} \\
(\mathrm{mg} / \mathrm{L})\end{array}$ & $\begin{array}{c}\mathrm{Mg}^{6} \\
(\mathrm{mg} / \mathrm{L})\end{array}$ & $\begin{array}{c}\mathrm{Fe}^{6} \\
(\mathrm{mg} / \mathrm{L})\end{array}$ & $\begin{array}{c}\mathrm{Mn}^{6} \\
(\mathrm{mg} / \mathrm{L})\end{array}$ & $\begin{array}{c}\mathrm{Mo}^{5} \\
(\mu \mathrm{g} / \mathrm{L})\end{array}$ & $\begin{array}{c}\mathrm{Ni}^{5} \\
(\mu \mathrm{g} / \mathrm{L})\end{array}$ & $\begin{array}{c}\mathrm{Pb}^{5} \\
(\mu \mathrm{g} / \mathrm{L})\end{array}$ & $\begin{array}{c}R^{5} b^{5} \\
(\mu g / L)\end{array}$ \\
\hline SG38-a & 365 & 19 & 2 & 56 & 93 & 146 & 10.7 & 1.54 & 6 & 17 & $<0.5$ & 4 \\
\hline SG38-b & 420 & 18 & 4 & 33 & 93 & 166 & 5.9 & 1.30 & 2 & 18 & $<0.5$ & 4 \\
\hline SG38-c & 382 & 13 & 6 & 14 & 114 & 167 & 4.7 & 0.71 & 5 & 43 & 0.6 & 6 \\
\hline SG40-a & 152 & 24 & 3 & 312 & 87 & 115 & 6.7 & 0.33 & 3 & 19 & $<0.5$ & 23 \\
\hline SG40-b & 213 & 23 & 2 & 268 & 103 & 140 & 12.1 & 0.36 & 3 & 21 & $<0.5$ & 25 \\
\hline SG40-c & 215 & 24 & 5 & 95 & 121 & 184 & 19.9 & 0.22 & 3 & 20 & $<0.5$ & 8 \\
\hline SG40-d & 322 & 15 & 2 & 25 & 100 & 171 & 6.4 & 0.89 & 1 & 25 & $<0.5$ & 6 \\
\hline SG41-a & 432 & 12 & 7 & 13 & 83 & 167 & 6.1 & 1.54 & 1 & 21 & $<0.5$ & 4 \\
\hline SG41-b & 439 & 10 & 3 & 8 & 77 & 168 & 7.4 & 1.13 & 2 & 20 & 0.7 & 3 \\
\hline SG41-c & 442 & 7 & 2 & 8 & 85 & 165 & 7.9 & 0.94 & 2 & 16 & $<0.5$ & 2 \\
\hline SG41-d & 422 & 7 & 3 & 8 & 81 & 153 & 10.9 & 0.87 & 1 & 17 & 0.6 & 3 \\
\hline SG41-e & 396 & 7 & 1 & 8 & 79 & 144 & 10.5 & 0.78 & 4 & 16 & $<0.5$ & 3 \\
\hline SG41-f & 378 & 10 & 3 & 8 & 81 & 140 & 5.7 & 0.59 & 4 & 16 & $<0.5$ & 3 \\
\hline SG41-g & -- & --- & --- & --- & --- & --- & --- & --- & --- & --- & --- & --- \\
\hline SG88-02-a & -- & --- & --- & -- & $\cdots$ & $\cdots$ & -- & --- & --- & -- & --- & --- \\
\hline SG88-02-b & 105 & 1 & 1 & 5 & 29 & 42.5 & 0.5 & 0.41 & 6 & 4 & $<0.5$ & 1 \\
\hline SG88-03-a & -- & --- & --- & --- & --- & -- & --- & --- & --- & --- & --- & --- \\
\hline SG88-03-b & 126 & 3 & 1 & 4 & 23 & 42.4 & 0.7 & 1.19 & 4 & 4 & $<0.5$ & 2 \\
\hline SG88-03-c & 103 & $<0.5$ & 1 & 4 & 27 & 38.9 & 0.7 & 0.67 & 3 & 4 & $<0.5$ & $<1$ \\
\hline SG99-a & 119 & $<0.5$ & 1 & 5 & 12 & 33.8 & 0.9 & 1.24 & 5 & 4 & $<0.5$ & $<1$ \\
\hline SG99-b & 78 & $<0.5$ & 10 & 2 & 15 & 24.5 & 0.5 & 0.38 & 2 & 4 & 2.4 & $<1$ \\
\hline SG99-c & 84 & $<0.5$ & 3 & 2 & 20 & 30.2 & 0.3 & 0.37 & 9 & 5 & $<0.5$ & $<1$ \\
\hline SG99-d & 73 & $<0.5$ & 2 & 4 & 19 & 25.8 & $<0.2$ & 0.24 & 7 & 3 & 0.7 & 1 \\
\hline
\end{tabular}


Table 7. Chemical composition of pore water withdrawn directly from core of the Canadian River alluvium that was obtained by freeze-shoe coring — Continued

\begin{tabular}{|c|c|c|c|c|c|c|c|c|c|c|c|}
\hline Sample & $\begin{array}{c}S^{5} \\
(\mu g / L)\end{array}$ & $\begin{array}{c}\mathrm{Se}^{5} \\
(\mu \mathrm{g} / \mathrm{L})\end{array}$ & $\begin{array}{c}\mathrm{Si}^{6} \\
(\mathrm{mg} / \mathrm{L})\end{array}$ & $\begin{array}{c}\mathrm{Sr}^{6} \\
(\mathrm{mg} / \mathrm{L})\end{array}$ & $\begin{array}{c}U^{5} \\
(\mu g / L)\end{array}$ & $\begin{array}{c}V^{5} \\
(\mu g / L)\end{array}$ & $\begin{array}{c}\mathrm{Zn}^{5} \\
(\mu \mathrm{g} / \mathrm{L})\end{array}$ & $\begin{array}{c}\text { Chloride }^{\prime} \\
\text { (mg/L) }\end{array}$ & $\begin{array}{c}\text { Bromide }^{7} \\
\text { (mg/L) }\end{array}$ & $\begin{array}{l}\text { Nitrate }^{\prime} \\
\text { (mg/L) }\end{array}$ & $\begin{array}{r}\text { Sulfate } \\
\text { (mg/L) }\end{array}$ \\
\hline SG38-a & $<1$ & 20 & 18.0 & 6.21 & $<0.5$ & 8 & 10 & 700 & 19 & 0.16 & 0.26 \\
\hline SG38-b & $<1$ & 18 & 18.4 & 6.99 & $<0.5$ & 7 & 20 & 710 & 19 & 0.14 & 0.21 \\
\hline SG38-c & 1 & 23 & 17.4 & 6.53 & 1.0 & 12 & 40 & 885 & 20 & $<0.20$ & 0.85 \\
\hline SG40-a & $<1$ & 30 & 16.2 & 3.51 & $<0.5$ & 9 & 30 & 985 & 10 & 0.34 & 1.6 \\
\hline SG40-b & $<1$ & 31 & 19.6 & 4.74 & $<0.5$ & 7 & 10 & 1030 & 9.1 & $<0.20$ & 0.94 \\
\hline SG40-c & $<1$ & 28 & 21.1 & 6.07 & $<0.5$ & 11 & 10 & 1050 & 8.8 & $<0.20$ & 0.53 \\
\hline SG40-d & $<1$ & 24 & 22.1 & 5.30 & $<0.5$ & 5 & 10 & 995 & 8.4 & $<0.20$ & 0.58 \\
\hline SG41-a & $<1$ & 19 & 17.3 & 6.07 & $<0.5$ & 5 & 60 & 890 & 19 & 0.36 & 61 \\
\hline SG41-b & $<1$ & 18 & 17.0 & 5.99 & $<0.5$ & 5 & 20 & 900 & 19 & 0.34 & 43 \\
\hline SG41-c & $<1$ & 17 & 17.0 & 5.83 & $<0.5$ & 4 & 10 & 895 & 19 & 0.30 & 22 \\
\hline SG41-d & $<1$ & 16 & 16.6 & 5.47 & 0.6 & 6 & 30 & 860 & 4.9 & $<0.20$ & 33 \\
\hline SG41-e & $<1$ & 15 & 16.0 & 5.14 & 0.9 & 4 & 10 & 830 & 18 & 0.27 & 41 \\
\hline SG41-f & $<1$ & 16 & 16.7 & 5.08 & 0.8 & 5 & 10 & $\cdots$ & $\cdots$ & --- & $\cdots$ \\
\hline SG41-g & --- & --- & --- & --- & --- & --- & --- & 755 & 18 & $<0.20$ & 35 \\
\hline SG88-02-a & --- & --- & --- & --- & --- & --- & --- & 105 & 1.1 & 1.2 & 100 \\
\hline SG88-02-b & $<1$ & 5 & 14.0 & 1.31 & $<0.5$ & 3 & $<10$ & --- & --- & --- & --- \\
\hline SG88-03-a & -- & -- & --- & --- & --- & -- & --- & 110 & 0.85 & $<0.20$ & 1.2 \\
\hline SG88-03-b & $<1$ & 4 & 12.3 & 1.42 & $<0.5$ & 4 & $<10$ & 99 & 0.91 & 0.22 & 83 \\
\hline SG88-03-c & $<1$ & 4 & 10.6 & 1.19 & $<0.5$ & 4 & 10 & 86 & 0.78 & $<0.20$ & 70 \\
\hline SG99-a & $<1$ & 1 & 12.3 & 1.28 & $<0.5$ & 3 & $<10$ & 34 & $<0.20$ & $<0.20$ & 99 \\
\hline SG99-b & $<1$ & 1 & 14.3 & 1.01 & $<0.5$ & 4 & 60 & 12 & $<0.20$ & $<0.20$ & 33 \\
\hline SG99-c & 2 & 1 & 15.3 & 1.19 & 1.0 & 5 & 60 & 10 & $<0.20$ & 4.4 & 26 \\
\hline SG99-d & $<1$ & 1 & 12.0 & 1.01 & 0.9 & 9 & 10 & 13 & $<0.20$ & $<0.20$ & 33 \\
\hline
\end{tabular}


Table 8. Composition of ground water collected from wells.

[Well location and depth listed in table 1. Existing wells were sampled at sites 38, 40, 41, 88, and WLMLF. Water at SG99 was collected from temporary drive point wells. Elements consistently below their detection limits and their respective detection limits in micrograms per liter are $\mathrm{Cd}(<0.5), \mathrm{Cs}(<1) ; \mathrm{Pb}(<0.5) ; \mathrm{Sb}(<1)$; and $\mathrm{U}(<0.5)$. $\mu \mathrm{S} / \mathrm{cm}$, microsiemens per centimeter at 25 degrees Celsius; $\mathrm{mg} / \mathrm{L}$, milligrams per liter: $\mu \mathrm{g} / \mathrm{L}$, micrograms per liter, mM, millimolar; ---, not determined \%o, per mil, for sulfur reported relative to Canon Diablo Troilite (CDT), for oxygen reported relative to standard mean ocean water (SMOW) ]

\begin{tabular}{|c|c|c|c|c|c|c|c|c|c|c|c|c|}
\hline Sample & $\mathrm{pH}^{1}$ & $\begin{array}{c}\text { Specific } \\
\text { Conductance }^{1} \\
(\mu \mathrm{S} / \mathrm{cm})\end{array}$ & $\begin{array}{c}\mathrm{Ag}^{2} \\
(\mu \mathrm{g} / \mathrm{L})\end{array}$ & $\begin{array}{c}\mathrm{Al}^{2} \\
(\mu \mathrm{g} / \mathrm{L})\end{array}$ & $\begin{array}{c}\mathrm{As}^{2} \\
(\mu \mathrm{g} / \mathrm{L})\end{array}$ & $\begin{array}{c}B^{3} \\
(\mu \mathrm{g} / \mathrm{L})\end{array}$ & $\begin{array}{c}B a^{3} \\
(\mu \mathrm{g} / \mathrm{L})\end{array}$ & $\begin{array}{c}\mathrm{Ca}^{3} \\
(\mathrm{mg} / \mathrm{L})\end{array}$ & $\begin{array}{c}\mathrm{Co}^{2} \\
(\mu \mathrm{g} / \mathrm{L})\end{array}$ & $\begin{array}{c}\mathrm{Cr}^{2} \\
(\mu \mathrm{g} / \mathrm{L})\end{array}$ & $\begin{array}{c}\mathrm{Cu}^{2} \\
(\mu \mathrm{g} / \mathrm{L})\end{array}$ & $\begin{array}{c}\mathrm{Fe}^{3} \\
(\mathrm{mg} / \mathrm{L})\end{array}$ \\
\hline MLS38-3 & --- & --- & $<0.5$ & $<10$ & 7 & 5060 & 4880 & 309 & 17 & 50 & 2 & 11.7 \\
\hline MLS38-5 & $-\cdots$ & --- & $<0.5$ & 30 & 10 & 7710 & 9390 & 449 & 23 & 30 & 6 & 17.6 \\
\hline MLS40-2 & --- & --- & $<0.5$ & 80 & 19 & 4670 & 5430 & 133 & 23 & 50 & 2 & 19.9 \\
\hline MLS40-3 & -- & --- & $<0.5$ & 10 & 14 & 4840 & 12500 & 276 & 23 & 50 & 2 & 18.8 \\
\hline MLS40-4 & -- & --- & $<0.5$ & $<10$ & 34 & 2580 & 3130 & 254 & 16 & 30 & 1 & 14.7 \\
\hline MLS41-3 & --- & --- & --- & --- & --- & --- & --- & --- & --- & --- & --- & --- \\
\hline MLS41-4 & $\cdots$ & $-\cdots$ & $-\cdots$ & $--\cdot$ & $\cdots$ & --- & --- & --- & $--\cdot$ & $--\cdot$ & $\cdots$ & $--\cdot$ \\
\hline MLS88-3 & $\cdots$ & --- & $<0.5$ & $<10$ & $<1$ & 500 & 1660 & 141 & $<0.5$ & $<10$ & 2 & 0.5 \\
\hline MLS88-4 & -- & --- & $<0.5$ & $<10$ & $<1$ & 460 & 460 & 125 & $<0.5$ & $<10$ & 1 & $<0.2$ \\
\hline SG99-S1 & 7.92 & 828 & --- & $--\cdot$ & --- & --- & --- & --- & --- & --- & --- & --- \\
\hline SG99-S2 & 8.12 & 801 & $\cdots$ & --- & -- & $--\cdot$ & $-\cdots$ & $--\cdot$ & $\cdots$ & $\cdots$ & $--\cdot$ & $\cdots$ \\
\hline SG99-S3 & 8.4 & 718 & $-\cdots$ & --- & --- & --- & --- & --- & --- & --- & --- & $-\cdots$ \\
\hline WLMLF & $-\cdots$ & --- & $<1^{\mathrm{e}}$ & $19^{\mathrm{e}}$ & $<100^{\mathrm{e}}$ & $3540^{\mathrm{e}}$ & $1500^{\mathrm{e}}$ & $89^{\mathrm{e}}$ & $32^{\mathrm{e}}$ & $<10^{\mathrm{e}}$ & $<10^{\mathrm{e}}$ & $1.5^{\mathrm{e}}$ \\
\hline
\end{tabular}

See footnotes at the end of the table 
Table 8. Composition of ground water collected from wells - Continued

\begin{tabular}{|c|c|c|c|c|c|c|c|c|c|c|c|c|}
\hline Sample & $\begin{array}{c}\mathrm{K}^{3} \\
(\mathrm{mg} / \mathrm{L})\end{array}$ & $\begin{array}{c}\mathrm{Li}^{2} \\
(\mu \mathrm{g} / \mathrm{L})\end{array}$ & $\begin{array}{c}\mathrm{Mg}^{3} \\
(\mathrm{mg} / \mathrm{L})\end{array}$ & $\begin{array}{c}\mathrm{Mn}^{3} \\
(\mathrm{mg} / \mathrm{L})\end{array}$ & $\begin{array}{c}\mathrm{Mo}^{2} \\
(\mu \mathrm{g} / \mathrm{L})\end{array}$ & $\begin{array}{c}\mathrm{Ni}^{2} \\
(\mu \mathrm{g} / \mathrm{L})\end{array}$ & $\begin{array}{c}\mathbf{R b}^{2} \\
(\mu \mathbf{g} / \mathrm{L})\end{array}$ & $\begin{array}{c}\mathrm{Se}^{2} \\
(\mu \mathrm{g} / \mathrm{L})\end{array}$ & $\begin{array}{c}\mathrm{Si}^{3} \\
(\mathrm{mg} / \mathrm{L})\end{array}$ & $\begin{array}{c}\mathrm{Sr}^{3} \\
(\mathrm{mg} / \mathrm{L})\end{array}$ & $\begin{array}{c}V^{2} \\
(\mu g / L)\end{array}$ & $\begin{array}{c}Z^{2} n^{2} \\
(\mu g / L)\end{array}$ \\
\hline MLS38-3 & 97 & 83 & 126 & 1.42 & $<1$ & 13 & 4 & 16 & 17.9 & 5.08 & 16 & 10 \\
\hline MLS38-5 & 15 & 149 & 198 & 0.81 & $<1$ & 21 & 5 & 26 & 16.3 & 9.12 & 14 & 20 \\
\hline MLS40-2 & 325 & 69 & 110 & 0.42 & 1 & 15 & 66 & 28 & 16.2 & 2.41 & 21 & 20 \\
\hline MLS40-3 & 154 & 108 & 159 & 0.44 & 1 & 21 & 8 & 28 & 19.3 & 6.22 & 18 & 20 \\
\hline MLS40-4 & 38 & 83 & 118 & 0.52 & 4 & 22 & 3 & 20 & 16.5 & 4.53 & 10 & 10 \\
\hline MLS41-3 & -- & -- & --- & --- & --- & --- & $\cdots$ & --- & --- & --- & --- & --- \\
\hline MLS41-4 & -- & --- & --- & -- & --- & -- & -- & -- & --- & -- & -- & --- \\
\hline MLS88-3 & --- & 21 & 44 & 0.80 & $<1$ & 4 & $<1$ & 4 & 14.2 & 1.77 & 2 & 10 \\
\hline MLS88-4 & 3 & 27 & 43 & 0.43 & $<1$ & 3 & $<1$ & 4 & 13.9 & 1.51 & 2 & 10 \\
\hline SG99 -S1 & 2 & --- & --- & --- & --- & --- & -- & --- & --- & -- & --- & -- \\
\hline SG99 -S2 & -- & --- & --- & -- & --- & $-\cdots$ & -- & --- & -- & -- & -- & -- \\
\hline SG99 -S3 & --- & -- & -- & --- & --- & -- & -- & -- & --- & -- & --- & -- \\
\hline WLMLF & $534^{7}$ & $43^{7}$ & $92^{7}$ & $102^{7}$ & $<20^{7}$ & $26^{7}$ & --- & --- & $15^{7}$ & $1610^{7}$ & $<20^{7}$ & $13^{7}$ \\
\hline
\end{tabular}

\begin{tabular}{ccccccc} 
Sample & $\begin{array}{c}\text { Bromide }^{4} \\
\text { (mg/L) }\end{array}$ & $\begin{array}{c}\text { Chloride }^{4} \\
\text { (mg/L) }\end{array}$ & $\begin{array}{c}\text { Sulfate }^{4} \\
\text { (mg/L) }\end{array}$ & $\begin{array}{c}\text { Sulfate }^{5} \\
\text { (mM) }\end{array}$ & $\begin{array}{c}\delta^{34} \mathbf{S}_{\text {sulfate }} \\
\text { \%oo }\end{array}$ & $\begin{array}{c}\delta^{\mathbf{1 8}} \mathbf{O}_{\text {sulfate }} \\
\text { \%oo }\end{array}$ \\
\hline MLS38-3 & 5.1 & 670 & 0.79 & 0.02 & 9.82 & 6.5 \\
\hline MLS38-5 & 8.1 & 1120 & 1.02 & 0.02 & 11.9 & 8.4 \\
\hline MLS40-2 & 9.5 & 780 & 1.40 & 0.04 & 8.73 & 10.0 \\
\hline MLS40-3 & 9.0 & 970 & 0.32 & 0.03 & 10.3 & 11.4 \\
\hline MLS40-4 & 6.5 & 660 & 5.07 & 0.07 & 48.8 & 17.0 \\
\hline MLS41-3 & --- & --- & --- & 2.8 & 23.0 & 14.8 \\
\hline MLS41-4 & --- & --- & --- & 5.52 & 10.1 & 11.0 \\
\hline MLS88-3 & 1.1 & 110 & 88.5 & 1 & 31.7 & 16.9 \\
\hline MLS88-4 & 0.76 & 106 & 99.7 & 1.14 & 30.5 & 20.0 \\
\hline SG99 -S1 & --- & --- & --- & 0.7 & 46.0 & 18.9 \\
\hline SG99 -S2 & --- & --- & --- & 1.15 & 19.8 & 16.8 \\
\hline SG99 -S3 & --- & --- & -- & 0.83 & 16.6 & 16.2 \\
\hline WLMLF & --- & --- & --- & 0.11 & 35.1 & 12.9
\end{tabular}

${ }^{1}$ field meter, $\quad{ }^{2}$ autotitrator, $\quad{ }^{3}$ inductively coupled plasma mass spectrometry, $\quad{ }^{4}$ direct coupled plasma spectrometry, $\quad{ }^{5}$ ion chromatography

${ }^{6}$ gravimetry $\quad{ }^{7}$ inductively coupled plasma atomic emission spectrometry 
Table 9. Chemical composition of water samples from the Canadian River.

[Sample locations presented in Figure 1 and table 2. Elements consistently below detection and their respective detection limits in micrograms per liter are: $\mathrm{Ag}(<1)$; $\mathrm{As}(<100)$; $\mathrm{Be}(<10)$; $\mathrm{Cd}(<5)$; $\mathrm{Cr}(<10) ; \mathrm{Cu}(<10)$; $\mathrm{Mo}(<20)$; $\mathrm{Pb}(<50) ; \mathrm{Sb}(<50) ; \mathrm{Ti}(<50) ; \mathrm{V}(<10)$. ---, not determined,

$\mathrm{mg} / \mathrm{L}$ milligrams per liter; $\mu \mathrm{g} / \mathrm{L}$, micrograms per liter; $\mu \mathrm{S} / \mathrm{cm}$, microsiemens per centimeter at 25 degrees Celsius; \%o, per mil, for sulfur reported relative to Canon Diablo Troilite (CDT), for oxygen relative to standard mean ocean water (SMOW)].

\begin{tabular}{|c|c|c|c|c|c|c|c|c|c|c|c|}
\hline Sample & $\mathrm{pH}^{1}$ & $\begin{array}{c}\text { Water } \\
\text { Temperature }{ }^{1} . \\
{ }^{\circ} \mathrm{C}\end{array}$ & $\begin{array}{c}\text { Alkalinity }^{2} \\
\left(\mathrm{mg} / \mathrm{L} \text { as } \mathrm{HCO}_{3}\right)\end{array}$ & $\begin{array}{c}\text { Specific }^{1} \\
\text { Conductance } \\
(\mu \mathrm{S} / \mathrm{cm})\end{array}$ & $\begin{array}{c}\mathrm{Al}^{3} \\
(\mathrm{mg} / \mathrm{L})\end{array}$ & $\begin{array}{c}B^{3} \\
(\mu g / L)\end{array}$ & $\begin{array}{c}B a^{3} \\
(\mu g / L)\end{array}$ & $\begin{array}{c}\mathrm{Ca}^{\mathrm{a}} \\
(\mathrm{mg} / \mathrm{L})\end{array}$ & $\begin{array}{c}\mathrm{Co}^{3} \\
(\mu \mathrm{g} / \mathrm{L}) \\
\end{array}$ & $\begin{array}{c}\mathrm{Fe}^{3} \\
(\mathrm{mg} / \mathrm{L})\end{array}$ & $\begin{array}{c}\mathrm{K}^{3} \\
\text { (mg/L) }\end{array}$ \\
\hline 02CR-01 & 8.35 & 17 & 227 & 3450 & $<0.01$ & 171 & 35 & 290 & 11 & $<0.02$ & 6.3 \\
\hline 02CR-02 & --- & -- & --- & 2850 & --- & --- & -- & --- & --- & --- & --- \\
\hline 02CR-03 & 8.33 & 19 & 217 & 1261 & $<0.01$ & 111 & 94 & 105 & $<10$ & $<0.02$ & 4.5 \\
\hline 02CR-04 & 8.61 & 24 & 187 & 1665 & $<0.01$ & 227 & 185 & 166 & $<10$ & $<0.02$ & 5.4 \\
\hline 02CR-05 & 8.86 & 28 & 285 & 650 & $<0.01$ & 158 & 101 & 48 & $<10$ & $<0.02$ & 7.6 \\
\hline 02CR-06 & 8.7 & 27 & 134 & 340 & $<0.01$ & 34 & 110 & 34 & $<10$ & $<0.02$ & 4.6 \\
\hline 02CR-07 & 8.63 & 25.5 & 240 & 1061 & $<0.01$ & 187 & 221 & 109 & $<10$ & 0.022 & 4.9 \\
\hline 02CR-08 & 8.35 & 13.3 & 201 & 2060 & $<0.01$ & 207 & 117 & 247 & $<10$ & $<0.02$ & 5.5 \\
\hline 02CR-09 & 8.3 & 14.9 & 200 & 2520 & $<0.01$ & 237 & 77 & 225 & $<10$ & $<0.02$ & 6.4 \\
\hline 02CR-09r & 8.3 & 14.9 & 201 & 2520 & $<0.01$ & 233 & 76 & 221 & $<10$ & $<0.02$ & 6.3 \\
\hline 02CR-10 & 8.39 & 14 & 256 & 2750 & $<0.01$ & 176 & 216 & 120 & $<10$ & $<0.02$ & 6.6 \\
\hline
\end{tabular}


Table 9. Chemical composition of Canadian River water samples_Continued

\begin{tabular}{|c|c|c|c|c|c|c|c|c|c|c|c|}
\hline Sample & $\begin{array}{c}\mathrm{Li}^{3} \\
(\mu \mathrm{g} / \mathrm{L})\end{array}$ & $\begin{array}{c}\mathrm{Mg}^{3} \\
(\mathrm{mg} / \mathrm{L})\end{array}$ & $\begin{array}{c}\mathrm{Mn}^{3} \\
(\mu \mathrm{g} / \mathrm{L})\end{array}$ & $\begin{array}{c}\mathrm{Na}^{3} \\
(\mathrm{mg} / \mathrm{L})\end{array}$ & $\begin{array}{c}\mathrm{Ni}^{3} \\
(\mu \mathrm{g} / \mathrm{L})\end{array}$ & $\begin{array}{c}P^{3} \\
(\mathrm{mg} / \mathrm{L})\end{array}$ & $\begin{array}{c}\mathrm{Si}^{3} \\
(\mathrm{mg} / \mathrm{L})\end{array}$ & $\begin{array}{c}\text { Sulfate }^{3} \\
\text { (mg/L) }\end{array}$ & $\begin{array}{c}\mathrm{Sr}^{3} \\
(\mu \mathrm{g} / \mathrm{L})\end{array}$ & $\begin{array}{c}\mathrm{Zn}^{3} \\
(\mu \mathrm{g} / \mathrm{L})\end{array}$ & $\begin{array}{c}\text { Fluoride }^{4} \\
\text { (mg/L) }\end{array}$ \\
\hline 02CR-01 & 96 & 192 & 37 & 383 & $<10$ & $<0.1$ & 0.99 & 2000 & 4970 & $<10$ & 0.5 \\
\hline 02CR-02 & --- & --- & -- & & --- & --- & --- & --- & --- & --- & -- \\
\hline 02CR-03 & 56 & 60 & 14 & 111 & $<10$ & $<0.1$ & 2.2 & 465 & 1620 & $<10$ & 0.58 \\
\hline 02CR-04 & 41 & 57 & $<10$ & 163 & $<10$ & $<0.1$ & 5.7 & 491 & 2090 & $<10$ & 0.74 \\
\hline 02CR-05 & 14 & 35 & 43 & 24 & $<10$ & 0.1 & 1.9 & 41 & 847 & $<10$ & 0.4 \\
\hline 02CR-06 & 8.5 & 12 & $<10$ & 11 & $<10$ & $<0.1$ & 5.5 & 36 & 655 & $<10$ & 0.21 \\
\hline 02CR-07 & 20 & 40 & $<10$ & 85 & $<10$ & $<0.1$ & 4.3 & 230 & 1070 & $<10$ & 0.52 \\
\hline 02CR-08 & 47 & 71 & 11 & 159 & $<10$ & $<0.1$ & 8.9 & 710 & 2710 & $<10$ & 0.81 \\
\hline 02CR-09 & 67 & 82 & $<10$ & 274 & $<10$ & $<0.1$ & 9.7 & 687 & 2990 & $<10$ & 1.2 \\
\hline 02CR-09r & 66 & 81 & $<10$ & 269 & $<10$ & $<0.1$ & 9.6 & 687 & 2940 & $<10$ & 1.2 \\
\hline 02CR-10 & 80 & 52 & 17 & 419 & $<10$ & $<0.1$ & 7.6 & 212 & 1940 & $<10$ & 2.2 \\
\hline
\end{tabular}

\begin{tabular}{|c|c|c|c|c|c|c|c|c|}
\hline Sample & $\begin{array}{c}\text { Chloride }^{\mathrm{b}} \\
\text { (mg/L) }\end{array}$ & $\begin{array}{c}\text { Bromide }^{b} \\
(\mathrm{mg} / \mathrm{L})\end{array}$ & $\begin{array}{c}\text { Nitrate }^{4} \\
\text { (mg/L) }\end{array}$ & $\begin{array}{c}\text { Phosphate }^{4} \\
\text { (mg/L) }\end{array}$ & $\begin{array}{c}\text { Sulfate }^{4} \\
\text { (mg/L) }\end{array}$ & $\begin{array}{c}\text { Sulfate }^{5} \\
\text { (mM) }\end{array}$ & $\begin{array}{c}{ }^{34} \mathrm{~S}_{\text {sulfate }} \\
(\%)\end{array}$ & $\begin{array}{c}{ }^{18} \mathrm{O}_{\text {sulfat }} \\
(\%)\end{array}$ \\
\hline 02CR-01 & 66 & 0.88 & $<0.3$ & $<0.3$ & 1910 & --- & -17.3 & 6.9 \\
\hline 02CR-03 & 34 & 0.56 & $<0.3$ & $<0.3$ & 434 & 4.4 & -12.2 & 9.0 \\
\hline 02CR-04 & 207 & 1.54 & $<0.3$ & $<0.3$ & 478 & 4.3 & 12.4 & 12.6 \\
\hline 02CR-05 & 17.3 & 0.16 & $<0.3$ & $<0.3$ & 37.9 & 0.88 & 10.8 & 15.2 \\
\hline 02CR-07 & 97 & 0.83 & $<0.3$ & $<0.3$ & 221 & 2.3 & 12.0 & 12.1 \\
\hline 02CR-08 & 204 & $<0.1$ & 0.69 & $<0.3$ & 673 & 7.4 & 11.9 & 12.4 \\
\hline 02CR-09 & 371 & $<0.1$ & $<0.3$ & $<0.3$ & 644 & 6.7 & 11.9 & 12.4 \\
\hline 02CR-09r & 378 & $<0.1$ & $<0.3$ & $<0.3$ & 646 & -- & --- & --- \\
\hline 02CR-10 & 663 & $<0.1$ & $<0.3$ & $<0.3$ & 190 & 2.1 & 10.5 & 12.1 \\
\hline
\end{tabular}

${ }^{1}$ field meters, $\quad{ }^{2}$ strandard acid titration $\quad{ }^{3}$ inductively coupled plasma atomic emission spectrometry $\quad{ }^{4}$ ion chromatography $\quad{ }^{5}$ gravimetry 


\section{Literature Cited}

Baedecker, M.J., and Cozzarelli, I.M., 1992, The determination and fate of unstable constituents of contaminated groundwater, in, Lesage, Suzanne and Jackson, R.E., Groundwater contamination and analysis at hazardous waste sites: Environmental Science and Pollution Control Series, 4, New York, Marcel Dekker, p. $425-461$.

Becker, C.J., 2002, Hydrology and leachate plume delineation at a closed municpal landfill, Norman, Oklahoma: U.S. Geological Survey, Water-Resources Investigations Report, 01-4168, 36 p.

Cozzarelli, I.M., Suflita, J.M., Ulrich, G.A., Harris, S.H., Scholl, M.A., Schlottmann, J.L., and Christenson, Scott, 2000, Geochemical and microbiological methods for evaluating anaerobic processes in an aquifer contaminated by landfill leachate: Environmental Science and Technology, v. 34, p. 4025-4033.

Folk, R.L., 1980, Petrology of Sedimentary Rocks: Austin, Texas, Hemphill Publishing Company, 85 p.

Heron, Gorm, Crouzet, Catherine, Bourg, A.C.M., and Christensen, T.H., 1994, Speciation of Fe(II) and Fe(III) in contaminated aquifer sediments using chemical extraction techniques: Environmental Science and Technology, v. 28, p. 1698-1705.

Goddard, E.N., Trask, P.D., De Ford, R.K., Rove, O.N., Singewald, J.T., and Overbeck, R.M., 1979, Rock-color Chart: Geological Society of America.

Kester, C.L., Rye, R.O., Johnson, C.A., Schwartz, Charles, and Homes, Charles, 2001, On-line sulfur isotope analysis of organic material by direct combustion: preliminary results and potential applications: Isotopes in Environmental Health Studies, v. 37, p. 53-65.

Lucius, J.E., and Bisdorf, R.J., 1995, Results of Geophysical Investigations near the Norman, Oklahoma, Municipal Landfill: U.S. Geological Survey, Open-File Report 95-825, 124 p.

Murphy, Fred, and Herkelrath, W.N., 1996, A sample-freezing drive shoe for a wire line piston core sampler: Ground Water Monitoring and Remediation, v. 16, no. 3, p. 86-90

Pollack, J.M., 1961, Significance of compositional and textural properties of south Canadian River channel sands, New Mexico, Texas and Oklahoma: Journal of Sedimentary Petrology, v. 31, p. 15-37.

Qian, Jianguo and Mopper, Kenneth, 1996, Automated high performance, high temperature combustion total organic carbon analyzer: Analytical Chemistry, v. 68, p. 3090-3097.

Rice, C.A., Tuttle, M.L., and Reynolds, R.L., 1993, The analysis of forms of sulfur in ancient sediments and sedimentary rocks: comments and cautions: Chemical Geology, v. 107, p. 83-95.

Schlottmann, J.L., 2001, Water chemistry near the closed Norman Landfill, Cleveland County, Oklahoma: U.S. Geological Survey Water-Resources Investigations Report 00-4238, 44 p.

Scholl, M.A., and Christenson, S.C., 1998, Spatial variation in hydraulic conductivity determined by slug tests in the Canadian River alluvium near the Norman Landfill, Norman, Oklahoma: U.S. Geological Survey, WaterResources Investigations Report 97-4292, 28 p.

Stookey, L.L., 1970, Ferrozine - a new spectrophotometric reagent for iron: Analytical Chemistry, v. 42, p. 779-781. 
Tuttle, M.L., Goldhaber, M.B., and Williamson, D.L., 1986, An analytical scheme for determining forms of sulfur in oil shales and associated rocks: Talanta, v. 33, p. 953-961. 